\begin{tabular}{|c|l|}
\hline Title & Synthesis of TFA-protected al pha A mino A cid Chloride via a V ilsmeier Reagent for Friedel-Crafts A cylation \\
\hline Author(s) & $\begin{array}{l}\text { Tachrim, Zetryana Puteri; Oida, Kazuhiro; Ohashi, Fumina; Kurokawa, Natsumi; W ang, Lei; Suzuki, Takey uki; } \\
\text { Hashimoto, Makoto }\end{array}$ \\
\hline Citation & $\begin{array}{l}\text { Letters in Organic Chemistry, 17(8), 645-653 } \\
\text { https:/doi.org/L0.2174/1570178617666200207111127 }\end{array}$ \\
\hline Issue Date & 2020-08 \\
\hline Doc URL & http://hdl.handle.net/2115/82842 \\
\hline Rights & $\begin{array}{l}\text { The published manuscript is available at EurekaSelect via } \\
\text { http://www.eurekaselect.com/openurl/content.php?genre=article\&doi=10.2174/1570178617666200207111127. }\end{array}$ \\
\hline Type & article (author version) \\
\hline File Information & Lett.Org.Chem.17(8) p.645-653.pdf \\
\hline
\end{tabular}

Instructions for use 


\title{
Synthesis of TFA-protected a-Amino Acid Chloride via a Vilsmeier Reagent for Friedel-Crafts acylation
}

\author{
Zetryana Puteri Tachrim, ${ }^{\mathrm{a}, \mathrm{b}}$ Kazuhiro Oida, ${ }^{\mathrm{a}}$ Fumina Ohashi, ${ }^{\mathrm{a}}$ Natsumi Kurokawa, ${ }^{\mathrm{a}}$ Lei Wang, ${ }^{\mathrm{c}}$ Takeyuki \\ Suzuki, ${ }^{\mathrm{d}}$ and Makoto Hashimoto ${ }^{\mathrm{a} *}$
}

${ }^{a}$ Division of Applied Bioscience, Graduate School of Agriculture, Hokkaido University, Kita 9, Nishi 9, Kita-ku, Sapporo 0608589, Japan; ${ }^{b}$ Program Study of Chemistry, Faculty of Mathematics and Natural Sciences, Institut Teknologi Bandung, Jalan Ganesha 10, Bandung 40132, Indonesia; 'Department of Pharmacy, School of Chemical Engineering, Dalian University of Technology, Dalian 116023, China; ${ }^{d}$ Division of Applied Science, The Institute of Scientific and Industrial Research, Osaka University, Osaka 5670047, Japan

\begin{tabular}{l} 
A R T I C L E H I S T O R Y \\
\hline Received: \\
Revised: \\
Accepted: \\
DOI:
\end{tabular}

\begin{abstract}
Amino acid chlorides are reactive coupling agents in amide (peptide) formation. The Vilsmeier reagent ((chloromethylene)dimethylammonium chloride) offers a convenient way to prepare $\alpha$ amino acid chlorides for peptide synthesis. Its use with $N$-trifluoracetyl (TFA)-protected isoleucine and allo-isoleucine is described. The ${ }^{1} \mathrm{H}$-NMR of the $\alpha$-proton signal offers a convenient way to monitor the chirality retention in the acid chloride forming reaction and subsequent Friedel-Crafts acylation of arenes and resulted in $\alpha$-amino acid aryl-ketone with no loss of chirality.
\end{abstract}

Keywords: Vilsmeier reagent, $\alpha$-Amino acid chloride, Friedel-Crafts acylation, $\alpha$-amino acid, $\alpha$-amino arylketone, racemization

\section{INTRODUCTION}

Activation of the C-terminal of $\mathrm{N}$-protected amino acids is an applicable method for forming amide (peptide) bonds. The synthesis of reactive agents for this reaction that possess a good leaving group is well-established [1]. The activation of the C-terminal of $\mathrm{N}$-protected amino acids has been extended into the synthesis of $N$-protected amino aryl-ketone via Friedel-Crafts acylation [2-9]. In recent studies, only a few $N$-protected amino acid derivatives containing a good leaving group, such as $N$-protected $N$ - $(\alpha-$ aminoacyl)benzotriazole [10] and $N$-trifluoroacetyl (TFA)protected $\alpha$-amino $N$-hydroxysuccinimide ester $[11,12,13]$, have been utilized as acyl donors in Friedel-Crafts acylation to give moderate yields of $\mathrm{N}$-protected amino aryl-ketone with chirality retention.

The use of $N$-protected amino acid chloride as an acyl donor in Friedel-Crafts acylation was first reported a few decades ago [14]. $\mathrm{N}$-protected amino acid chloride is also typically used as a highly reactive coupling agent for peptide synthesis $[15,16]$. In spite of this high reactivity, $N$-protected amino acid chloride sometimes accelerates racemization, which might occur via the promotion of other intermediates $[4,15]$ during reaction. Previously, $\mathrm{SOCl}_{2}[4,8,16,17]$ and $(\mathrm{COCl})_{2}[3,7,9]$ were typically employed for $N$-protected amino acid chloride preparation and were directly used as potential acyl donors in Friedel-Crafts acylation. Further development showed that the activation of $N$-protected

*Address correspondence to this author at the Division of Applied Bioscience, Graduate School of Agriculture, Hokkaido University, Kita 9, Nishi 9, Kita-ku, Sapporo 0608589, Japan, e-mail: hasimoto@abs.agr.hokudai.ac.jp. amino acids with (chloromethylene)dimethylammonium chloride (Vilsmeier reagent) [18] at a low temperature can form a clean acid chloride intermediate for a peptide coupling reaction [15].

When using $\mathrm{N}$-protected amino acid chloride to obtain $\mathrm{N}$ protected amino aryl-ketone, possible racemization has usually been checked by utilizing a chiral shift reagent [7] or optical rotations [9]. Moreover, a limited number of studies have reported the gas chromatography method to determine chirality in the reaction by utilizing $N$-protected amino acid chloride [5,17]. Isoleucine and its diastereomer alloisoleucine are important natural $\alpha$-amino acids that possess two chiral centers in their structure. We previously reported on the activation of the C-terminal of TFA-protected isoleucine or its diastereomer allo-isoleucine derivatives via an $N$-hydroxysuccinimide ester for the Friedel-Crafts acylation of arenes [11]. Based on this previous work, the utilization of isoleucine (and allo-isoleucine) derivatives appeared to offer a convenient method for the detection by ${ }^{1} \mathrm{H}-\mathrm{NMR}$ of any nonequivalent signals corresponding to optical loss at the $\alpha$-position. Since a Vilsmeier reagent was only used in the formation of $N$-protected $\alpha$-amino acid chloride for a peptide coupling reaction, TFA-protected isoleucine or its diastereomer allo-isoleucine acid chloride derivatives are introduced by using a Vilsmeier reagent in this paper. In this study, the potential acyl donors, TFAprotected isoleucine, and its diastereomer allo-isoleucine acid chloride derivatives are directly subjected to FriedelCrafts acylation. Furthermore, a comprehensive study on the retention of the $\alpha$-chiral center during the sequence is undertaken. The use of TFA-protected amino acid chloride, which allows one to retain chirality, is expected to prompt 
investigations into the synthesis of other TFA-protected $\alpha$ amino aryl-ketone derivatives.

\section{RESULTS AND DISCUSSION}

The selection of suitable conditions for the reactions of optically active $\alpha$-amino acids is necessary, and several considerations are needed. First is the use of the $N$-terminal protection group in $\alpha$-amino acids. In early work on the utilization of acid chloride for aminoacylations, a phthaloyl protecting group [19-21] or tosyl group [22] were reported to produce racemization or undesired side-reactions during the synthesis or application of acid chloride. The use of TFA groups for $\mathrm{N}$-terminal protection was previously considered to be less desirable in peptide synthesis due to the use of trifluoroacetic anhydride [15], such as a TFA group source, which triggers racemization. A much cleaner method was then developed by using ethyl trifluoroacetate [23,24], which was mainly used for $N$-terminal TFA protection.

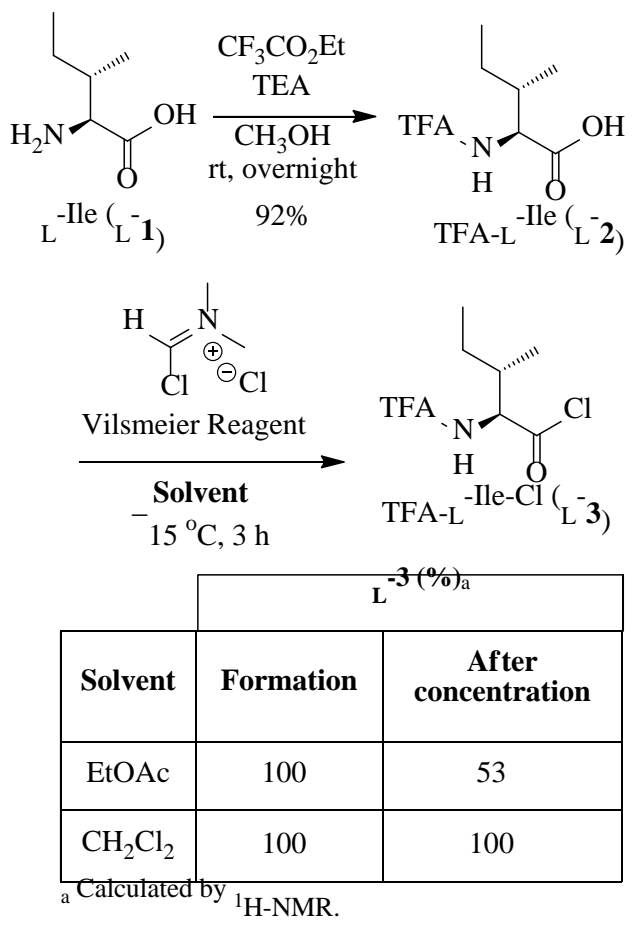

Fig. (1). Synthesis of TFA-L-Ile-Cl (L-3) from TFA-L-Ile$\mathrm{OH}$ (L-2), which was prepared from L-Ile (L-1), with Vilsmeier reagent in EtOAc and $\mathrm{CH}_{2} \mathrm{Cl}_{2}$.

The use of such TFA-protected $\alpha$-amino acids as materials to prepare acid chlorides has been previously reported [3,7,9] and has also shown high chirality retention when applied in Friedel-Crafts acylation. Accordingly, the optical active L-isoleucine (L-1) was initially protected in our study by using ethyl trifluoroacetate in the presence of triethylamine in methanol [24,25] to generate TFA-L-Ile (L2) (Fig. 1). Racemization might be observed during $N$ protected $\alpha$-amino acid chloride formation and might be dependent on experimental conditions, among which reaction temperature is the most critical variable that can be used to control racemization when a Vilsmeier reagent is used to form acid chloride derivatives [15]. Preliminary, L-2 was dissolved in ethyl acetate and then reacted with the
Vilsmeier reagent at $-15{ }^{\circ} \mathrm{C}$ for $3 \mathrm{~h}$. TFA-L-isoleucine acid chloride (TFA-L-Ile-Cl, L-3) formation was validated via the dilution of an aliquot of the reaction mixture in $\mathrm{CDCl}_{3}$ and subjecting it to ${ }^{1} \mathrm{H}-\mathrm{NMR}$.

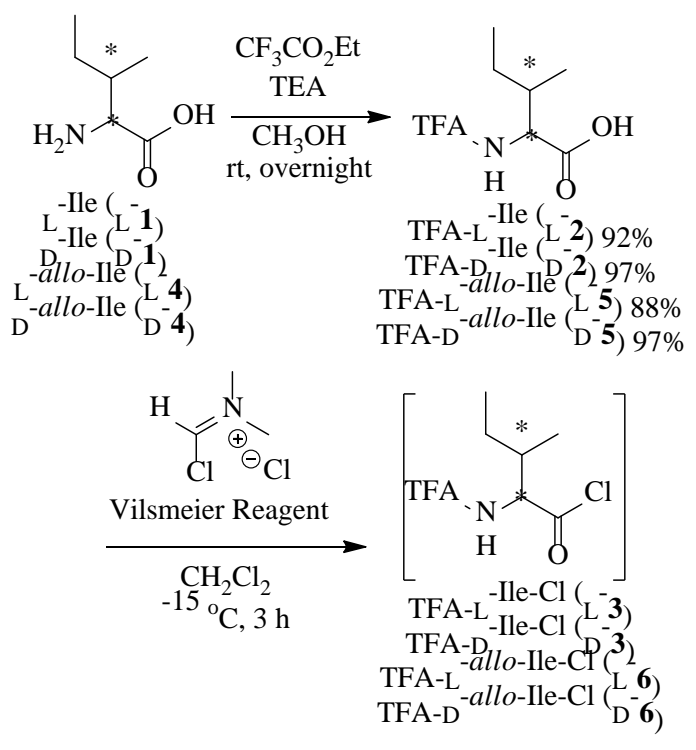

Fig. (2). In situ synthesis of TFA-L-/D-Ile-Cl (L-/D-3) and TFA-L-/D-allo-Ile-Cl (L-/D-6) by the utilization of a Vilsmeier reagent.

In the middle-field region, the detection of the L-3 $\alpha$ proton was slightly shifted down field $(\delta=4.84 \mathrm{ppm}$, see Supplementary Material for detailed ${ }^{1} \mathrm{H}-\mathrm{NMR}$ analysis) compared to its starting material of TFA-L-Ile (L-2, $\delta=4.69$ ppm). During the investigation, L-2 was completely consumed (indicating that, in an ethyl acetate reaction system, acid chloride can be formed effectively) and produced TFA-L-Ile-Cl (L-3). ${ }^{1} \mathrm{H}-\mathrm{NMR}$ showed no other $\alpha$ proton, indicating that no epimerization took place at the $\alpha$ position's chiral center. The attempt to isolate L-3 was conducted by ethyl acetate removal under reduced pressure at ambient temperatures. In spite of L-3 being determined quantitatively by NMR analysis before work up, L-3 was found to be hydrolyzed into L-2 without any loss of $\alpha$-proton chirality (Fig. 1). Since the solubility of dichloromethane in a Vilsmeier reagent is reported to be higher than that in ethyl acetate [15] and easier to remove by evaporation than ethyl acetate, the reaction solvent was changed to dichloromethane. The use of dichloromethane as a solvent for the reaction of TFA-L-Ile (L-2) with a Vilsmeier reagent at $-15{ }^{\circ} \mathrm{C}$ for $3 \mathrm{~h}$ effectively resulted in TFA-L-Ile-Cl (L-3). No hydrolysis of L-3 was observed during dichloromethane removal under reduced pressure at $0{ }^{\circ} \mathrm{C}$ (Fig. 1), but the generated DMF that formed after Vilsmeier reagent activation could not be removed after the treatment. The removal of DMF was also attempted by washing the dichloromethane solution with $\mathrm{H}_{2} \mathrm{O}$ or $1 \mathrm{M} \mathrm{HCl}$, and it was found that the hydrolysis of acid chloride occurred. The DMF/HCl complex in the Vilsmeier reaction system plays a role in stabilizing acid chloride and suppressing racemization [15]. Both dichloromethane and DMF are also known as solvents for peptide synthesis, so the TFA-L-Ile-Cl (L-3) resulting from Vilsmeier reagent 
utilization is assumed to be suitable for direct application without any further treatment.

The stability of TFA-L-Ile-Cl (L-3) was demonstrated by maintaining its dichloromethane solution at $-20{ }^{\circ} \mathrm{C}$ after completing the reaction. In ${ }^{1} \mathrm{H}-\mathrm{NMR}$, the TFA-L-Ile-Cl (L-3) $\alpha$-proton signals indicate the retention of the chiral center after storage for at least for 6 days. After confirming TFA-LIle-Cl (L-3) stability, the Vilsmeier reagent was also used with other isoleucine isomers: D-isoleucine (D-1) and L-/Dallo-Ile (L-/D-4). Optically active D-Ile and L-/D-allo-Ile were first protected by TFA groups, resulting in TFA-D-Ile (D-2) and TFA-L-/D-allo-Ile (L-/D-5). Similar to our previously reported study [11], during $N$-terminal protection by TFA, only the $\alpha$-proton signal of L-/D-2 in ${ }^{1} \mathrm{H}-\mathrm{NMR}(\delta=4.69 \mathrm{ppm}$, Supplementary Material) could be observed. No trace of L/D-5 $(\delta=4.77 \mathrm{ppm})$ was detected, ensuring that the chirality retention of $N$-TFA isoleucine derivatives was suitable for use in the next reaction (Fig. 2).

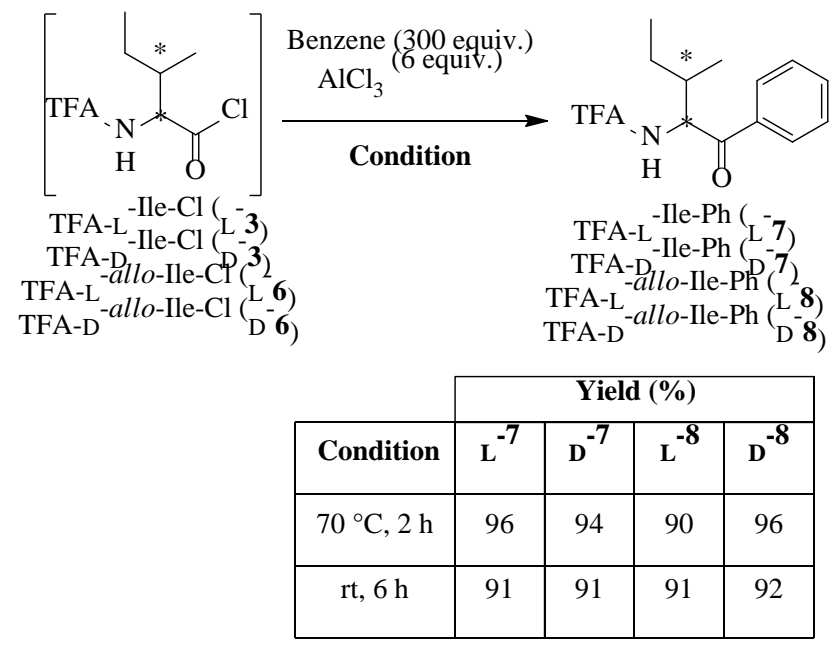

Fig. (3). Utilization of TFA-L-/D-Ile-Cl (L-/D-7) and TFA-L/D-allo-Ile-Cl (L-/D-8) for the Friedel-Crafts acylation of benzene at $70^{\circ} \mathrm{C}$ for $2 \mathrm{~h}$ or under room temperature for $6 \mathrm{~h}$.

Next, the TFA-L-/D-Ile (L-/D-2) and TFA-L-/D-allo-Ile (L(D-5) were subjected to a Vilsmeier reagent, under which the in situ formation of the desired TFA-L-/D-Ile-Cl (L-/D-3) and TFA-L-/D-allo-Ile-Cl (L-/D-6) could be detected by ${ }^{1} \mathrm{H}-\mathrm{NMR}$ (Fig. 2). The resulting L-/D-3 and L-/D-6 exhibit $\alpha$-proton signals at $\delta=4.84 \mathrm{ppm}$ and $\delta=4.98 \mathrm{ppm}$, respectively (see Supplementary Material for detail ${ }^{1} \mathrm{H}-\mathrm{NMR}$ analysis). This chemical shift difference appears sufficient for checking epimerization during acid chloride formation and ensuring the chirality retention of acid chloride, which can be used for further application. The resulting acid chloride was then utilized as an acyl donor in the Friedel-Crafts acylation of benzene, without further treatment (Fig. 3).

Direct Friedel-Crafts acylation of benzene with TFA-L/D-Ile-Cl (L-/D-3) and TFA-L-/D-allo-Ile-Cl (L-/D-6) was started by conducting similar condition with previous utilization of the TFA- $\alpha$-amino acid $N$-hydroxysuccinimide ester [11], by the used of $\mathrm{AlCl}_{3}$ at $70{ }^{\circ} \mathrm{C}$ for $2 \mathrm{~h}$. The use of a temperature of $70{ }^{\circ} \mathrm{C}$ for the reaction of TFA-L-/D-Ile-Cl (L/D-3) and TFA-L-/D-allo-Ile-Cl (L-/D-6) with benzene resulted in an excellent yield of TFA-L-/D-Ile-Ph (L-/D-7) and TFA-L-/D-allo-Ile-Ph (L-/D-8, Fig. 3). A reaction at 70 ${ }^{\circ} \mathrm{C}$ was found to be suitable, since it resulted in no loss of chirality among the desired acylated products. Next, TFA-L/D-Ile-Cl (L-/D-3) and TFA-L-/D-allo-Ile-Cl (L-/D-6) were subjected to the acylation of benzene at room temperature for $6 \mathrm{~h}$, which also resulted in an excellent yield of A TFA-L-/DIle-Ph (L-/D-7) and TFA-L-/D-allo-Ile-Ph (L-/D-8, Fig. 3). Although L-/D-3 and L-/D-6 showed high reactivity for acylation of benzene at room temperature, but they are unsuitable for storage and prone to hydrolysis which in opposite with previously reported study by utilization of $N$ hydroxysuccinimide ester [11].

There is no doubt that acid chlorides are very reactive compounds for use in Friedel-Crafts acylation since within 6 h, $N$-TFA- $\alpha$-amino phenylketone derivatives can be formed at excellent yields under room temperature. Previously, optically active $N$-TFA- $\alpha$-amino acid chlorides prepared by $(\mathrm{COCl})_{2}$ [7] were considered to be less effective for FriedelCrafts acylation due to their low yield of the desired $N$-TFA$\alpha$-amino aryl-ketone compared to the yields of TFA-L-/D-Ile$\mathrm{Cl}$ (L-/D-3) and TFA-L-/D-allo-Ile-Cl (L-/D-6) produced by using the Vilsmeier reagent. The $\alpha$-proton $(\delta=5.60 \mathrm{ppm})$ of the resulting aryl ketone L-/D-7 clearly shows an absence of any epimeric signals that contribute to L-/D-8 $(\delta=5.74 \mathrm{ppm}$, Supplementary Material). These results indicate that either L/D-7 or its diastereomer, L-/D-8, exhibited no epimerization after acylation and that the acid chloride produced by the Vilsmeier reagent can be applied in the Friedel-Crafts acylation of benzene to produce an $\alpha$-amino phenyl ketone without loss of chirality. Unlike a previous study on $N$-TFA$\alpha$-amino acid chloride [7] utilization in the Friedel-Crafts acylation of arenes, a chiral shift reagent is not needed in isoleucine derivatives since its epimeric $\alpha$-proton signals can be easily detected by ${ }^{1} \mathrm{H}-\mathrm{NMR}$. The activation with $\mathrm{AlCl}_{3}$ as a Lewis acid is presumably preferred for forming the acylium cation, which rapidly performs acylation and results in an optically active TFA- $\alpha$-amino phenyl ketone. Moreover, TFA-protection for Friedel-Crafts acylation via acid chloride utilization is believed to be suitable for this type of reaction because oxazolinone formation, which is commonly formed when another carbonyl-protecting group [4] is used, can be hampered.

The Friedel-Crafts acylation of anisole appears more difficult due to the greater basicity of alkoxybenzene and has been reported to fail with some $N$-carbamate-protected $\alpha$ amino acid chlorides [4]. In this study, TFA-L-Ile-Cl (L-3) was subjected to anisole by using $\mathrm{AlCl}_{3}$ at $70{ }^{\circ} \mathrm{C}$ for $2 \mathrm{~h}$ (Table 1 Entry 1). TFA-L-isoleucine 4-methoxyphenyl ketone (TFA-L-Ile-Ph(4-OMe), L-9) was formed with a good yield as the major product, together with its regioisomer, L10 (the L-9 to L-10 ratio is 8:1, Table 1, Entry 1). This result indicates the importance of $\mathrm{N}$-terminal protection groups in supporting suitable conditions for Friedel-Crafts acylation under Lewis acid activation and led us to subject TFA-L-Ile$\mathrm{Cl}$ (L-3) to toluene by utilizing $\mathrm{AlCl}_{3}$ (Table 1 Entries 2-5). The high reactivity of $N$-protected $\alpha$-amino acid chloride towards toluene has previously been established [5]. TFA-Lisoleucine 4-methylphenyl ketone (TFA-L-Ile- $\mathrm{Ph}(4-\mathrm{Me})$, L11) and TFA-L-isoleucine 2-methylphenyl ketone (TFA-L$\mathrm{Ile}-\mathrm{Ph}(2-\mathrm{Me})$, L-12) were formed as major and minor products, respectively. The proportions of $\mathrm{L}-\mathbf{1 1}$ and $\mathrm{L}-\mathbf{1 2}$ were calculated as 7.2:1 and $3.4: 1$ at $70{ }^{\circ} \mathrm{C}$ and room temperature, respectively (Table 1, Entries 2-3). Acylation 
still occurred when the reaction temperature was lowered to $-40{ }^{\circ} \mathrm{C}$ and $-80{ }^{\circ} \mathrm{C}$, although the reaction took a longer time (16 $\mathrm{h}$ and 3 days, respectively, Table 1, Entries 4-5). By lowering the temperature, the 4-methylphenyl ketone isomer L-11 was still formed in a higher yield than the 2methylphenyl ketone, L-12. The different proportions of the L-11 and L-12 isomers demonstrate the high reactivity of the TFA- $\alpha$-amino acid chloride when used with an electron-rich acyl acceptor, such as toluene.

Table 1. Friedel-Crafts acylation of arenes with TFA-LIle-CI (L-3).

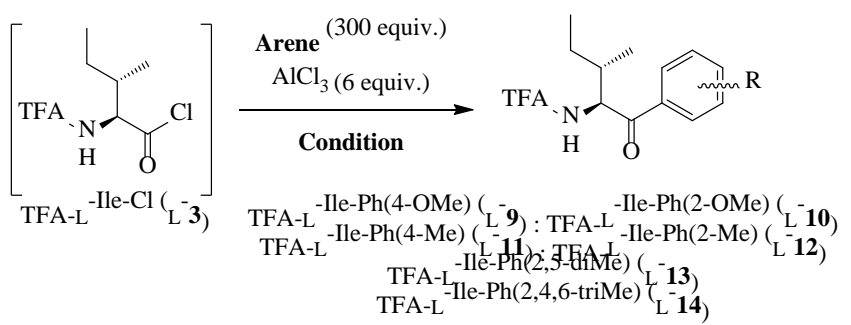

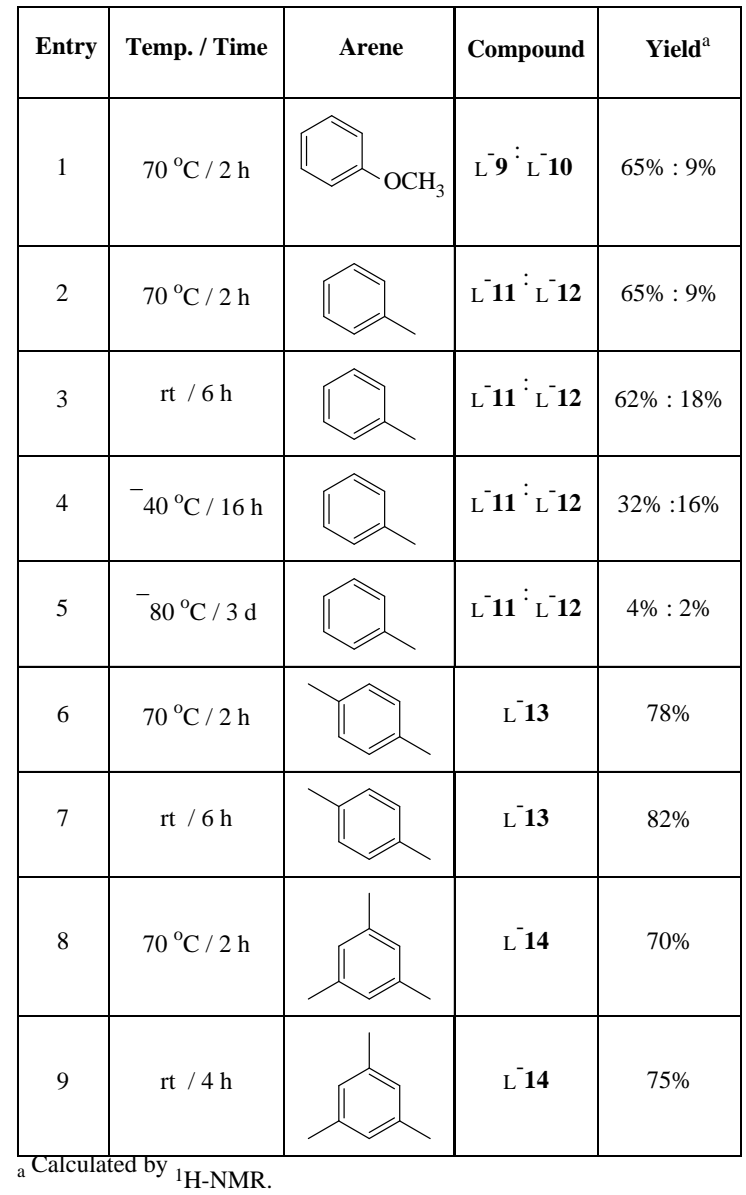

Further subjection of TFA-L-Ile-Cl (L-3) to $p$-xylene and mesitylene by using $\mathrm{AlCl}_{3}$ at $70{ }^{\circ} \mathrm{C}$ or under room temperature (Table 1 Entries 6-9), showed high reactivity of the acid chloride for direct acylation which resulted in excellent yields TFA-L-Ile-Ph(2,5-diMe) (L-13) and TFA-LIle- $\mathrm{Ph}(2,4,6$-triMe) (L-14), respectively. In addition, utilization of TFA-L-Ile-Cl (L-3) with phenol and $o$-cresol were not suitable for the reaction due to the hydrolysis of L-3 were preferred during the reaction.

The application of acid chlorides via the utilization of a Vilsmeier reagent, and their application in the Friedel-Crafts acylation of benzene, could be broadened by the use of other natural $\alpha$-amino acids (Fig. 4). $\alpha$-Amino acids, such as glycine (15), optically active L-/D-alanine (L-/D-18), and L/D-lysine (L-/D-21), underwent direct TFA-protection at their $\mathrm{N}$-terminals, resulting in TFA-Gly (16), TFA-L-/D-Ala (L-/D19), and TFA-L-/D-Lys(TFA) (L-/D-22), respectively. The protection of the two $\mathrm{N}$-terminals of the L-/D-lysine molecule was obtained by using twice the amount of triethylamine and ethyl trifluoroacetate as reagents, resulting in TFA-L-/DLys(TFA) (L-/D-22) (Fig. 4).

The reactions of TFA-Gly (16), TFA-L-/D-Ala (L-/D-19), and TFA-L-/D-Lys(TFA) (L-/D-22) with the Vilsmeier reagent resulted in the corresponding $\alpha$-amino acid chlorides, which were then applied directly to the Friedel-Crafts acylation of benzene to give TFA-Gly-Ph (17), TFA-L-/DAla-Ph (L-/D-20), and TFA-L-/D-Lys(TFA)-Ph (L-/D-23), respectively, in excellent yields while retaining chirality. Unlike the utilization of the $\alpha$-amino acid $N$ hydroxysuccinimide ester [11] derivatives that require a longer reaction time with benzene, the use of acid chloride as a representative acyl donor is considered an excellent reagent for Friedel-Crafts acylation, as confirmed by its utilization, resulting in an excellent yield of $\alpha$-amino-phenyl ketones at room temperature within $6 \mathrm{~h}$.

The introduction of the diamino groups of L-/D-lysine did not interfere with any step in the sequence. A longer aliphatic side-chain of L-/D-lysine compared to those of glycine or alanine was also found to be independent of either acid chloride formation or acylation. The utilization of TFAL-/D-Lys(TFA) (L-/D-19) for the formation of the associated acid chloride is difficult to generate with the use of the typically used reagents, $\mathrm{SOCl}_{2}$ and $(\mathrm{COCl})_{2}$. These reagents are known to hamper Friedel-Crafts acylation, and, although they can easily be removed by reducing pressure, the resulting acid chloride might be lost during the work-up, resulting in a low yield of the acylated product. Therefore, $N$-protected L-/D-lysine is not well-studied for its modification and application via acid chloride formation. Since in situ acid chloride formation by a Vilsmeier reagent is sufficiently stable for direct utilization in Friedel-Crafts acylation, a high yield of L-/D-23 can be achieved.

\section{EXPERIMENTAL SECTION}

\subsection{General}

All reagents used were of analytical grade. FT-IR (Fourier-transform infrared spectroscopy) spectra were recorded on a FT-IR 4100 spectrometer (JASCO, Tokyo, Japan). NMR spectra were measured by an EX 270 spectrometer (JEOL, Tokyo, Japan). Optical rotations were measured at $23^{\circ} \mathrm{C}$ on a JASCO DIP370 polarimeter (JASCO, Tokyo, Japan). HR-MS ESI spectra were obtained with a Waters UPLC ESI-TOF mass spectrometer (Waters, Milford, CT, USA). 


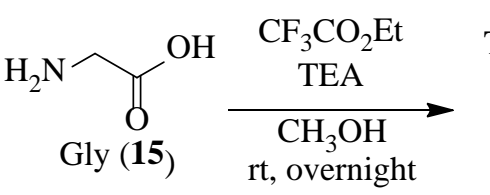<smiles>CC(C)NCC(=O)O</smiles>

TFA-Gly (16) 85\%

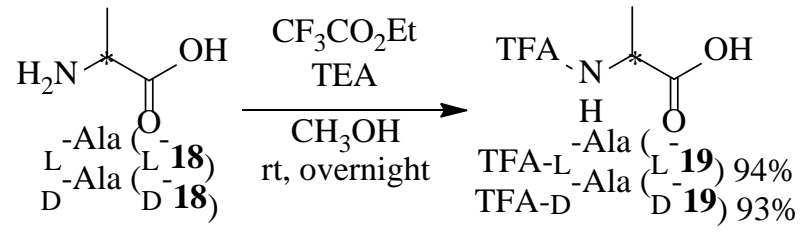

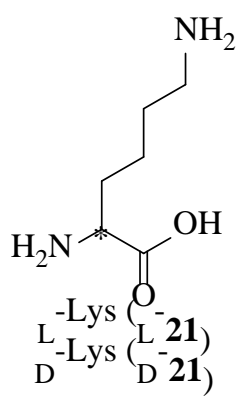

TFA

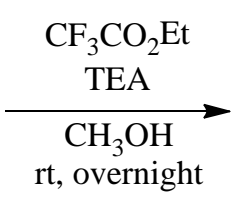

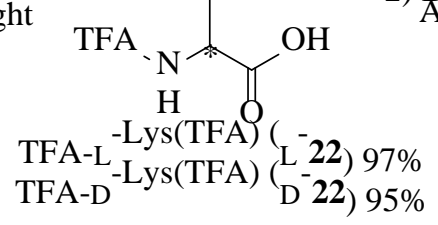

1) $\mathrm{CH}_{2}{ }_{2} \mathrm{Cl}_{2},-{ }^{\circ}{ }^{\circ} \mathrm{C}, 3 \mathrm{H}$

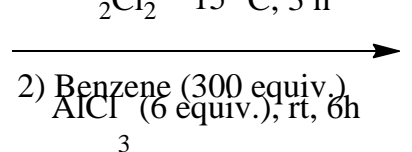

1) Vilsmeier Reagent ${ }_{2} \mathrm{Cl}_{2},{ }^{-} 15{ }^{\circ} \mathrm{C}, 3 \mathrm{~h}$ 2) Benzene (300 equiv, 3

\section{1) Vilsmeier Reagent} ${ }_{2} \mathrm{Cl}_{2},{ }^{-} 15^{\circ} \mathrm{C}, 3 \mathrm{~h}$

2) Benzene (300 equiv, $)$<smiles>[Li][Mg]</smiles><smiles>CC(C)NCC(=O)c1ccccc1</smiles>

TFA-Gly-Ph (17) 90\%

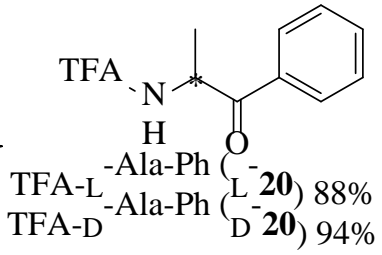

TFA

Fig. (4). Synthesis of various TFA-protected $\alpha$-amino acids and their application in Friedel-Crafts acylation via acid chloride derivatives prepared with the use of Vilsmeier reagent.

\subsection{General procedure for the preparation of TFA-L-/D- $\alpha$-amino acid}

The TFA-L-/D- $\alpha$-amino acid was prepared by using reported procedure $[24,25]$ with slight modification. The corresponding amino groups of $\alpha$-amino acid underwent TFA protection by using ethyl trifluoroacetate in the presence of triethylamine in methanol to generate TFA-L-/D$\alpha$-amino acid.

\subsection{1. (2S,3S)-3-Methyl-2-(2,2,2-trifluoroacetamido)- pentanoic acid (TFA-L-Ile, L-2).}

Yield 92\%. Colorless amorphous mass. $[\alpha]_{\mathrm{D}}{ }^{23}=+55$ (c 1.0, $\mathrm{CHCl}_{3}$ ). IR (neat): 3294, 2968, 1739, $1694 .{ }^{1} \mathrm{H}-\mathrm{NMR}$ (270 $\left.\mathrm{MHz} \mathrm{CDCl}_{3}\right): 6.74\left(d,{ }^{3} \mathrm{~J}(\mathrm{H}, \mathrm{H})=8.6 \mathrm{~Hz}, 1 \mathrm{H}, \mathrm{NH}\right), 4.69$ $\left(d d,{ }^{3} J(\mathrm{H}, \mathrm{H})=8.6,4.3 \mathrm{~Hz}, 1 \mathrm{H}, \mathrm{CHNH}\right), 2.14-1.99(m, 1 \mathrm{H}$, $\left.\mathrm{CHCH}_{3}\right), 1.60-1.45\left(m, 1 \mathrm{H}, \mathrm{CH}_{2} \mathrm{CH}_{3}\right), 1.36-1.19(m, 1 \mathrm{H}$, $\left.\mathrm{CH}_{2} \mathrm{CH}_{3}\right), 1.02-0.95\left(m, 6 \mathrm{H}, 2 \times \mathrm{CH}_{3}\right) .{ }^{13} \mathrm{C}-\mathrm{NMR}(67.5$ $\left.\mathrm{MHz}, \mathrm{CDCl}_{3}\right): 175.4,157.3\left(q,{ }^{2} J(\mathrm{C}, \mathrm{F})=38.0 \mathrm{~Hz}\right), 115.6(q$, $\left.{ }^{1} J(\mathrm{C}, \mathrm{F})=287.7 \mathrm{~Hz}\right), 56.8,37.6,24.9,15.2$, 11.3. HR-MS: $228.0865\left([M+\mathrm{H}]^{+}, \mathrm{C}_{8} \mathrm{H}_{13} \mathrm{~F}_{3} \mathrm{NO}_{3}{ }^{+}\right.$; calc.228.0848).

3.2.2. (2R,3R)-3-Methyl-2-(2,2,2-trifluoroacetamido)pentanoic acid (TFA-D-Ile, D-2) [23,24].

Yield $97 \%$. Colorless amorphous mass. $[\alpha]_{\mathrm{D}}{ }^{23}=-55$ (c 1.0, $\mathrm{CHCl}_{3}$ ). IR (neat): 3293, 2973, 1740, 1699. ${ }^{1} \mathrm{H}-\mathrm{NMR}$ (270 $\left.\mathrm{MHz}, \mathrm{CDCl}_{3}\right): 6.75\left(d,{ }^{3} J(\mathrm{H}, \mathrm{H})=8.6 \mathrm{~Hz}, 1 \mathrm{H}, \mathrm{NH}\right), 4.69(d d$, $\left.{ }^{3} J(\mathrm{H}, \mathrm{H})=8.6,4.3 \mathrm{~Hz}, 1 \mathrm{H}, \mathrm{CHNH}\right), 2.16-1.99(m, 1 \mathrm{H}$, $\left.\mathrm{CHCH}_{3}\right), 1.62-1.43\left(m, 1 \mathrm{H}, \mathrm{CH}_{2} \mathrm{CH}_{3}\right), 1.36-1.18(m, 1 \mathrm{H}$, $\left.\mathrm{CH}_{2} \mathrm{CH}_{3}\right), 1.13-0.89\left(m, 6 \mathrm{H}, 2 \times \mathrm{CH}_{3}\right) .{ }^{13} \mathrm{C}-\mathrm{NMR}(67.5$ $\left.\mathrm{MHz}, \mathrm{CDCl}_{3}\right): 75.3,157.0\left(q,{ }^{1} \mathrm{~J}(\mathrm{C}, \mathrm{F})=37.6 \mathrm{~Hz}\right), 115.6(q$, $\left.{ }^{1} J(\mathrm{C}, \mathrm{F})=287.5 \mathrm{~Hz}\right), 56.7,37.7,25.0,15.2$, 11.5. HR-MS: $228.0842\left([M+\mathrm{H}]^{+}, \mathrm{C}_{8} \mathrm{H}_{13} \mathrm{~F}_{3} \mathrm{NO}_{3}{ }^{+}\right.$; calc. 228.0848).
3.2.3. (2S,3R)-3-Methyl-2-(2,2,2-trifluoroacetamido)pentanoic acid (TFA-L-allo-Ile, L-5).

Yield 88\%. Colorless amorphous mass. $[\alpha]_{\mathrm{D}}{ }^{23}=+24$ (c 1.0, $\left.\mathrm{CHCl}_{3}\right)$. IR (neat): 3287, 2971, 1719. ${ }^{1} \mathrm{H}-\mathrm{NMR}(270 \mathrm{MHz}$, $\left.\mathrm{CDCl}_{3}\right): 6.81\left(d,{ }^{3} \mathrm{~J}(\mathrm{H}, \mathrm{H})=8.6 \mathrm{~Hz}, 1 \mathrm{H}, \mathrm{NH}\right), 4.77\left(d d,{ }^{3} \mathrm{~J}(\mathrm{H}\right.$, $\mathrm{H})=8.6,3.6 \mathrm{~Hz}, 1 \mathrm{H}, \mathrm{CHNH}), 2.17-2.06\left(\mathrm{~m}, 1 \mathrm{H}, \mathrm{CHCH}_{3}\right)$, 1.54-1.37 ( $\left.m, 1 \mathrm{H}, \mathrm{CH}_{2} \mathrm{CH}_{3}\right), 1.36-1.17\left(m, 1 \mathrm{H}, \mathrm{CH}_{2} \mathrm{CH}_{3}\right)$, $1.02-0.94\left(m, 6 \mathrm{H}, 2 \times \mathrm{CH}_{3}\right) .{ }^{13} \mathrm{C}-\mathrm{NMR}\left(67.5 \mathrm{MHz}, \mathrm{CDCl}_{3}\right)$ : 175.9, $157.5\left(q,{ }^{2} J(\mathrm{C}, \mathrm{F})=37.8 \mathrm{~Hz}\right), 115.7\left(q,{ }^{1} \mathrm{~J}(\mathrm{C}, \mathrm{F})=\right.$ $287.7 \mathrm{~Hz}), 55.9,37.6,26.1,14.4$, 11.6. HR-MS: 228.0848 $\left([\mathrm{M}+\mathrm{H}]^{+}, \mathrm{C}_{8} \mathrm{H}_{13} \mathrm{~F}_{3} \mathrm{NO}_{3}{ }^{+}\right.$; calc. 228.0848).

3.2.4.

(2R,3S)-3-Methyl-2-(2,2,2-trifluoroacetamido)pentanoic acid (TFA-D-allo-Ile, D-5).

Yield 97\%. Colorless amorphous mass. $[\alpha]_{\mathrm{D}}{ }^{23}=-24$ (c 1.0, $\left.\mathrm{CHCl}_{3}\right)$. IR (neat): 3302, 2971, 1708. ${ }^{1} \mathrm{H}-\mathrm{NMR}(270 \mathrm{MHz}$, $\left.\mathrm{CDCl}_{3}\right): 6.66\left(d,{ }^{3} J(\mathrm{H}, \mathrm{H})=8.6 \mathrm{~Hz}, 1 \mathrm{H}, \mathrm{NH}\right), 4.77\left(d d,{ }^{3} \mathrm{~J}(\mathrm{H}\right.$, $\mathrm{H})=8.9,3.6 \mathrm{~Hz}, 1 \mathrm{H}, \mathrm{CHNH}), 2.18-2.01\left(\mathrm{~m}, 1 \mathrm{H}, \mathrm{CHCH}_{3}\right)$, 1.56-1.36 ( $\left.m, 1 \mathrm{H}, \mathrm{CH}_{2} \mathrm{CH}_{3}\right), 1.36-1.14\left(m, 1 \mathrm{H}, \mathrm{CH}_{2} \mathrm{CH}_{3}\right)$, $1.04-0.87\left(m, 6 \mathrm{H}, 2 \times \mathrm{CH}_{3}\right) .{ }^{13} \mathrm{C}-\mathrm{NMR}\left(67.5 \mathrm{MHz}, \mathrm{CDCl}_{3}\right)$ : 175.7, $157.4\left(q,{ }^{2} J(\mathrm{C}, \mathrm{F})=37.8 \mathrm{~Hz}\right), 115.7\left(q,{ }^{1} \mathrm{~J}(\mathrm{C}, \mathrm{F})=\right.$ $287.7 \mathrm{~Hz}), 55.7,37.6,26.1,14.3$, 11.5. HR-MS: 228.0883 $\left(\left[M+\mathrm{H}^{+}, \mathrm{C}_{8} \mathrm{H}_{13} \mathrm{~F}_{3} \mathrm{NO}_{3}{ }^{+}\right.\right.$; calc. 228.0848).

3.2.5. 2-(2,2,2-Trifluoroacetamido)acetic acid (TFA-Gly, 16) $[23,25-27]$.

Yield 85\%. Colorless amorphous mass. IR (neat): 3299, 2992, 1682. ${ }^{1} \mathrm{H}-\mathrm{NMR}\left(270 \mathrm{MHz}\right.$, acetone- $\left.\mathrm{D}_{6}\right): 8.72$ (br s, $1 \mathrm{H}$, $\mathrm{COOH}), 4.13\left(d, 2 \mathrm{H},{ }^{3} \mathrm{~J}(\mathrm{H}, \mathrm{H})=6.3 \mathrm{~Hz}, \mathrm{CH}_{2} \mathrm{NH}\right) .{ }^{13} \mathrm{C}-\mathrm{NMR}$ (67.5 MHz, acetone- $\left.\mathrm{D}_{6}\right): 170.0,158.2\left(\mathrm{q},{ }^{2} \mathrm{~J}(\mathrm{C}, \mathrm{F})=36.9\right.$ $\mathrm{Hz}), 117.0\left(q,{ }^{1} \mathrm{~J}(\mathrm{C}, \mathrm{F})=87.2 \mathrm{~Hz}\right), 41.4$. HR-MS: 172.0213 $\left([M+\mathrm{H}]^{+}, \mathrm{C}_{4} \mathrm{H}_{5} \mathrm{~F}_{3} \mathrm{NO}_{3}{ }^{+}\right.$; calc. 172.0222). 
3.2.6. (S)-2-(2,2,2-Trifluoroacetamido)propanoic acid (TFA-L-Ala, L-19) [15,23,25,28,29].

Yield 94\%. Colorless amorphous mass. $[\alpha]_{\mathrm{D}}{ }^{23}=+38$ (c 1.0, $\mathrm{CHCl}_{3}$ ). IR (neat): 3330, 3006, 1752. ${ }^{1} \mathrm{H}-\mathrm{NMR}(270 \mathrm{MHz}$, $\left.\mathrm{CDCl}_{3}\right): 7.39$ (br s, $\left.1 \mathrm{H}, \mathrm{COOH}\right), 6.96($ br s, $1 \mathrm{H}, \mathrm{NH}), 4.72-$ $4.61\left(m, 1 \mathrm{H}, \mathrm{CHCH}_{3}\right), 1.57\left(d,{ }^{3} \mathrm{~J}(\mathrm{H}, \mathrm{H})=7.3 \mathrm{~Hz}, 3 \mathrm{H}\right.$, $\left.\mathrm{CHCH}_{3}\right) .{ }^{13} \mathrm{C}-\mathrm{NMR}\left(67.5 \mathrm{MHz}, \mathrm{CDCl}_{3}\right): 176.4,157.0(q$, $\left.{ }^{2} J(\mathrm{C}, \mathrm{F})=38.0 \mathrm{~Hz}\right), 115.5\left(q,{ }^{1} \mathrm{~J}(\mathrm{C}, \mathrm{F})=287.2 \mathrm{~Hz}\right), 48.5$, 17.5. HR-MS: $186.0380\left([M+\mathrm{H}]^{+}, \mathrm{C}_{5} \mathrm{H}_{7} \mathrm{~F}_{3} \mathrm{NO}_{3}{ }^{+}\right.$; calc. 186.0378).

3.2.7. (R)-2-(2,2,2-Trifluoroacetamido)propanoic acid (TFA-D-Ala, D-19) [28].

Yield 93\%. Colorless amorphous mass. $[\alpha]_{\mathrm{D}}{ }^{23}=-38$ (c 1.0, $\left.\mathrm{CHCl}_{3}\right)$. IR (neat): 3293, 3006, 1751. ${ }^{1} \mathrm{H}-\mathrm{NMR}(270 \mathrm{MHz}$, $\left.\mathrm{CDCl}_{3}\right): 7.91$ (br s, $\left.1 \mathrm{H}, \mathrm{COOH}\right), 7.03($ br s, $1 \mathrm{H}, \mathrm{NH}), 4.72-$ $4.61\left(m, 1 \mathrm{H}, \mathrm{CHCH}_{3}\right), 1.58\left(d,{ }^{3} \mathrm{~J}(\mathrm{H}, \mathrm{H})=7.3 \mathrm{~Hz}, 3 \mathrm{H}\right.$, $\left.\mathrm{CHCH}_{3}\right) .{ }^{13} \mathrm{C}-\mathrm{NMR}\left(67.5 \mathrm{MHz}, \mathrm{CDCl}_{3}\right): 176.4,157.0$ (q, $\left.{ }^{2} J(\mathrm{C}, \mathrm{F})=38.0 \mathrm{~Hz}\right), 115.5\left(q,{ }^{1} \mathrm{~J}(\mathrm{C}, \mathrm{F})=287.3 \mathrm{~Hz}\right), 48.5$, 17.4. HR-MS: $186.0365\left([M+\mathrm{H}]^{+}, \mathrm{C}_{5} \mathrm{H}_{7} \mathrm{~F}_{3} \mathrm{NO}_{3}{ }^{+}\right.$; calc. 186.0378).

3.3. Procedure for the preparation of TFA-L-/D-Lys(TFA) (L-/D-22). Triethylamine (60 mmol, 3 equiv.) was added to a solution of $\alpha$-amino acid ( $20 \mathrm{mmol}$ ) in $\mathrm{MeOH}(10 \mathrm{~mL})$. After 5 min, ethyl trifluoroacetate (52 mmol, 2.6 equiv.) was added and the reaction was allowed to stir overnight. The solvent was removed by rotary evaporation and the remaining residue was dissolved in $\mathrm{H}_{2} \mathrm{O}$ and acidified with concentrated $\mathrm{HCl}$. The mixture was extracted with ethyl acetate for several times and the organic layers were combined and washed with brine, dried by $\mathrm{MgSO}_{4}$, filtered, and concentrated by rotary evaporation.

3.3.1. (S)-2,6-Bis(2,2,2-trifluoroacetamido)hexanoic acid (TFA-L-Lys(TFA), L-22) [14,23,29,30].

Yield $97 \%$. Colorless amorphous mass. $[\alpha]_{\mathrm{D}}{ }^{23}=-7.0$ (c 1.0, $\mathrm{MeOH})$. IR (neat): 3329, 3102, 2945, 1741. ${ }^{1} \mathrm{H}-\mathrm{NMR}$ (270 $\left.\mathrm{MHz}, \mathrm{D}_{2} \mathrm{O}\right): 4.38\left(q,{ }^{3} \mathrm{~J}(\mathrm{H}, \mathrm{H})=4.9 \mathrm{~Hz}, 1 \mathrm{H}, \mathrm{CHNH}\right), 3.22(t$, $\left.{ }^{3} J(\mathrm{H}, \mathrm{H})=6.8 \mathrm{~Hz}, 2 \mathrm{H}, \mathrm{CH}_{2} \mathrm{NH}\right), 1.89\left(t d,{ }^{3} J(\mathrm{H}, \mathrm{H})=14.6\right.$, $\left.8.8 \mathrm{~Hz}, 1 \mathrm{H}, \mathrm{CHCH}_{2} \mathrm{CH}_{2}\right), 1.73\left(t d,{ }^{3} J(\mathrm{H}, \mathrm{H})=14.6,8.8 \mathrm{~Hz}\right.$, $\left.1 \mathrm{H}, \mathrm{CHCH}_{2} \mathrm{CH}_{2}\right), 1.56-1.46\left(m, 2 \mathrm{H}, \mathrm{CH}_{2} \mathrm{CH}_{2} \mathrm{NH}\right), 1.33$ (q, $\left.{ }^{3} J(\mathrm{H}, \mathrm{H})=7.6 \mathrm{~Hz}, 2 \mathrm{H}, \mathrm{CHCH}_{2} \mathrm{CH}_{2}\right) .{ }^{13} \mathrm{C}-\mathrm{NMR}(67.5 \mathrm{MHz}$, $\left.\mathrm{CD}_{3} \mathrm{OD}\right): 173.8,159.2\left(q,{ }^{2} J(\mathrm{C}, \mathrm{F})=37.4 \mathrm{~Hz}\right), 159.1\left(q,{ }^{2} J(\mathrm{C}\right.$, $\mathrm{F})=36.7 \mathrm{~Hz}), 117.5\left(q,{ }^{1} \mathrm{~J}(\mathrm{C}, \mathrm{F})=286.4 \mathrm{~Hz}\right), 117.4\left(q,{ }^{1} \mathrm{~J}(\mathrm{C}\right.$, $\mathrm{F})=286.6 \mathrm{~Hz}), 53.9,40.4,31.3,29.2$, 24.2. HR-MS: 339.0797 ([M+ H] $]^{+}, \mathrm{C}_{10} \mathrm{H}_{13} \mathrm{~F}_{6} \mathrm{~N}_{2} \mathrm{O}_{4}{ }^{+}$; calc. 339.0780).

3.3.2. (R)-2,6-Bis(2,2,2-trifluoroacetamido)hexanoic acid (TFA-D-Lys(TFA), D-22).

Yield 95\%. Colorless amorphous mass. $[\alpha]_{\mathrm{D}}{ }^{23}=+7.0$ (c 1.0, $\mathrm{MeOH})$. IR (neat): 3313, 3099, 2944, 1745. ${ }^{1} \mathrm{H}-\mathrm{NMR}$ (270 $\left.\mathrm{MHz}, \mathrm{D}_{2} \mathrm{O}\right): 4.48\left(q,{ }^{3} \mathrm{~J}(\mathrm{H}, \mathrm{H})=4.6 \mathrm{~Hz}, 1 \mathrm{H}, \mathrm{CHNH}\right), 3.32(t$, $\left.{ }^{3} J(\mathrm{H}, \mathrm{H})=6.8 \mathrm{~Hz}, 2 \mathrm{H}, \mathrm{CH}_{2} \mathrm{NH}\right), 1.99\left(t d,{ }^{3} J(\mathrm{H}, \mathrm{H})=13.7\right.$, $\left.7.8 \mathrm{~Hz}, 1 \mathrm{H}, \mathrm{CHCH}_{2} \mathrm{CH}_{2}\right), 1.83\left(t d,{ }^{3} J(\mathrm{H}, \mathrm{H})=13.7,7.8 \mathrm{~Hz}\right.$, $1 \mathrm{H}, \mathrm{CHCH}_{2} \mathrm{CH}_{2}$ ), 1.66-1.56 ( $\left.m, 2 \mathrm{H}, \mathrm{CH}_{2} \mathrm{CH}_{2} \mathrm{NH}\right), 1.42$ (q, $\left.{ }^{3} J(\mathrm{H}, \mathrm{H})=7.8 \mathrm{~Hz}, 2 \mathrm{H}, \mathrm{CHCH}_{2} \mathrm{CH}_{2}\right) \cdot{ }^{13} \mathrm{C}-\mathrm{NMR}(67.5 \mathrm{MHz}$, $\left.\mathrm{CD}_{3} \mathrm{OD}\right): 173.9,159.2\left(q,{ }^{2} J(\mathrm{C}, \mathrm{F})=37.6 \mathrm{~Hz}\right), 159.1\left(q,{ }^{2} J(\mathrm{C}\right.$, $\mathrm{F})=36.7 \mathrm{~Hz}), 117.5\left(q,{ }^{1} J(\mathrm{C}, \mathrm{F})=286.4 \mathrm{~Hz}\right), 117.3\left(q,{ }^{1} \mathrm{~J}(\mathrm{C}\right.$, $\mathrm{F})=286.4 \mathrm{~Hz}), 53.9,40.4,31.4,29.1,24.1$. HR-MS: $339.0770\left([M+\mathrm{H}]^{+}, \mathrm{C}_{10} \mathrm{H}_{13} \mathrm{~F}_{6} \mathrm{~N}_{2} \mathrm{O}_{4}{ }^{+}\right.$; calc. 339.0780).
3.4. General procedure for the preparation of TFA-L-/D$\alpha$-amino acid chloride

TFA-L-/D- $\alpha$-amino acid $(0.408 \mathrm{mmol})$ was dissolved in 1 $\mathrm{ml}$ of dichloromethane, cooled to $-15^{\circ} \mathrm{C}$ and then Vilsmeier reagent ( $0.938 \mathrm{mmol}, 2.3$ equiv.) was divided into 3 portions which added every 30 minutes. Then, the mixture was reacted for 3 hours. After completion of the reaction, a part of the solution in the reaction system was taken and added to $\mathrm{CDCl}_{3}$ to measure ${ }^{1} \mathrm{H}$-NMR to confirm the formation of TFA-L-/D- $\alpha$-amino acid chloride.

\subsection{General procedure for the preparation of TFA-L-/D- $\alpha$-amino aryl-ketones via acid chloride utilization}

The corresponding to TFA-L-/D- $\alpha$-amino acid chloride $(0.204 \mathrm{mmol}$ in $500 \mu \mathrm{l}$ dichloromethane solution) was dissolved in pre-cooled benzene (61.2 mmol, 300 equiv.), aluminum chloride (1.224 mmol, 6 equiv.) was added, and the reaction was carried out at desired temperature. After completion of the reaction, the mixture was poured into an ethyl acetate- $\mathrm{H}_{2} \mathrm{O}$ two-phase system to quench the reaction. The organic layer was washed with sat. $\mathrm{NaHCO}_{3}$, sat. $\mathrm{NaCl}$, dried over $\mathrm{MgSO}_{4}$, and then evaporated. The crude product was purified by column chromatography on silica (ethyl acetate/hexane 1:3 for L-/D-7, L-/D-8, 17, L-/D-20, L-/D-23 and diethyl ether/hexane 1:6 for L-9 and L-11, L-13, L-14).

3.5.1. 2,2,2-Trifluoro- $N-((2 S, 3 S)-3-m e t h y l-1-0 x 0-1-$ phenylpentan-2-yl)acetamide (TFA-L-Ile-Ph, L-7).

Yield 96\%. Colorless needles. $[\alpha]_{\mathrm{D}}{ }^{23}=+70$ (c 2.0, $\mathrm{CHCl}_{3}$ ). IR (neat): 3317, 3071, 2972, 1720, 1694. ${ }^{1} \mathrm{H}-\mathrm{NMR}$ (270 $\left.\mathrm{MHz}^{\mathrm{CDCl}} \mathrm{CD}_{3}\right): 7.97\left(d,{ }^{3} \mathrm{~J}(\mathrm{H}, \mathrm{H})=7.7 \mathrm{~Hz}, 2 \mathrm{H}, \mathrm{Ar}-\mathrm{H}\right), 7.65(t$, $\left.{ }^{3} J(\mathrm{H}, \mathrm{H})=7.7 \mathrm{~Hz}, 1 \mathrm{H}, \mathrm{Ar}-\mathrm{H}\right), 7.52\left(t,{ }^{3} \mathrm{~J}(\mathrm{H}, \mathrm{H})=7.7 \mathrm{~Hz}, 2 \mathrm{H}\right.$, Ar-H), $7.29(s, 1 \mathrm{H}, \mathrm{NH}), 5.60\left(d d,{ }^{3} J(\mathrm{H}, \mathrm{H})=8.7,4.1 \mathrm{~Hz}\right.$, $1 \mathrm{H}, \mathrm{CHNH}), 2.08-1.96\left(\mathrm{~m}, 1 \mathrm{H}, \mathrm{CHCH}_{3}\right), 1.41-1.24(\mathrm{~m}, 1 \mathrm{H}$, $\left.\mathrm{CH}_{2} \mathrm{CH}_{3}\right), 1.10-0.95$ ( $m$, 4H, overlap $\mathrm{CH}_{2} \mathrm{CH}_{3}$ and $\left.\mathrm{CHCH}_{3}\right)$, $0.81\left(t,{ }^{3} \mathrm{~J}(\mathrm{H}, \mathrm{H})=7.3 \mathrm{~Hz}, 3 \mathrm{H}, \mathrm{CH}_{2} \mathrm{CH}_{3}\right) .{ }^{13} \mathrm{C}-\mathrm{NMR}(67.5$ $\left.\mathrm{MHz}, \mathrm{CDCl}_{3}\right): 197.6,157.2\left(q,{ }^{2} J(\mathrm{C}, \mathrm{F})=37.4 \mathrm{~Hz}\right), 134.7$, 134.4, $129.1(2 \times \mathrm{CH}), 128.7(2 \times \mathrm{CH}), 115.9\left(q,{ }^{1} \mathrm{~J}(\mathrm{C}, \mathrm{F})=\right.$ $287.7 \mathrm{~Hz}), 58.5,38.8,23.7,16.2$, 11.4. HR-MS: 288.1202 $\left([M+\mathrm{H}]^{+}, \mathrm{C}_{14} \mathrm{H}_{17} \mathrm{~F}_{3} \mathrm{NO}_{2}{ }^{+}\right.$; calc. 288.1211).

3.5.2. 2,2,2-Trifluoro- $N-((2 R, 3 R)-3-m e t h y l-1-0 \times 0-1-$ phenylpentan-2-yl)acetamide (TFA-D-Ile-Ph, D-7).

Yield 94\%. Colorless needles. $[\alpha]_{\mathrm{D}}{ }^{23}=-70$ (c 2.0, $\mathrm{CHCl}_{3}$ ). IR (neat): 3337, 3075, 2969, 1721, 1699. ${ }^{1} \mathrm{H}-\mathrm{NMR}$ (270 $\left.\mathrm{MHz}, \mathrm{CDCl}_{3}\right): 7.97\left(d,{ }^{3} \mathrm{~J}(\mathrm{H}, \mathrm{H})=7.9 \mathrm{~Hz}, 2 \mathrm{H}, \mathrm{Ar}-\mathrm{H}\right), 7.65(t$, $\left.{ }^{3} J(\mathrm{H}, \mathrm{H})=7.9 \mathrm{~Hz}, 1 \mathrm{H}, \mathrm{Ar}-\mathrm{H}\right), 7.53\left(t,{ }^{3} J(\mathrm{H}, \mathrm{H})=7.9 \mathrm{~Hz}, 2 \mathrm{H}\right.$, Ar-H), $7.27(b r s, 1 \mathrm{H}, \mathrm{NH}), 5.60\left(d d,{ }^{3} J(\mathrm{H}, \mathrm{H})=8.7,4.1 \mathrm{~Hz}\right.$, $1 \mathrm{H}, \mathrm{CHNH}), 2.10-1.96\left(\mathrm{~m}, 1 \mathrm{H}, \mathrm{CHCH}_{3}\right), 1.38-1.24(\mathrm{~m}, 1 \mathrm{H}$, $\left.\mathrm{CH}_{2} \mathrm{CH}_{3}\right), 1.10-0.95\left(m, 4 \mathrm{H}\right.$, overlap $\mathrm{CH}_{2} \mathrm{CH}_{3}$ and $\left.\mathrm{CHCH}_{3}\right)$, $0.82\left(\mathrm{t},{ }^{3} \mathrm{~J}(\mathrm{H}, \mathrm{H})=7.4 \mathrm{~Hz}, 3 \mathrm{H}, \mathrm{CH}_{2} \mathrm{CH}_{3}\right) .{ }^{13} \mathrm{C}-\mathrm{NMR}(67.5$ $\left.\mathrm{MHz}, \mathrm{CDCl}_{3}\right):$ 197.5, $157.2\left(q,{ }^{2} J(\mathrm{C}, \mathrm{F})=37.4 \mathrm{~Hz}\right), 134.7$, 134.4, $129.1(2 \times \mathrm{CH}), 128.7(2 \times \mathrm{CH}), 115.9\left(q,{ }^{1} J(\mathrm{C}, \mathrm{F})=\right.$ $287.3 \mathrm{~Hz}), 58.5,38.8,23.7,16.2$, 11.4. HR-MS: 288.1218 $\left([M+\mathrm{H}]^{+}, \mathrm{C}_{14} \mathrm{H}_{17} \mathrm{~F}_{3} \mathrm{NO}_{2}^{+}\right.$; calc. 288.1211).

3.5.3. 2,2,2-Trifluoro- $N$-((2S,3S)-1-(4-methoxyphenyl)-3methyl-1-oxopentan-2-yl)acetamide (TFA-L-Ile-Ph(4OMe), L-9).

Yield $65 \%$. Colorless oil. $[\alpha]_{\mathrm{D}}^{23}=+66$ (c 1.0, $\mathrm{CHCl}_{3}$ ). IR (neat): 3319, 3078, 2935, 1726, 1673. ${ }^{1} \mathrm{H}-\mathrm{NMR}(270 \mathrm{MHz}$, $\left.\mathrm{CDCl}_{3}\right): 7.97\left(d,{ }^{3} \mathrm{~J}(\mathrm{H}, \mathrm{H})=8.9 \mathrm{~Hz}, 2 \mathrm{H}, \mathrm{Ar}-\mathrm{H}\right), 7.36(\mathrm{br} \mathrm{s}$, $1 \mathrm{H}, \mathrm{NH}), 6.99\left(\mathrm{~d},{ }^{3} \mathrm{~J}(\mathrm{H}, \mathrm{H})=8.9 \mathrm{~Hz}, 2 \mathrm{H}, \mathrm{Ar}-\mathrm{H}\right), 5.55(d d$, $\left.{ }^{3} J(\mathrm{H}, \mathrm{H})=8.7,4.5 \mathrm{~Hz}, 1 \mathrm{H}, \mathrm{CHNH}\right), 3.90\left(\mathrm{~s}, 3 \mathrm{H}, \mathrm{OCH}_{3}\right)$, 
2.10-1.95 ( $\left.m, 1 \mathrm{H}, \mathrm{CHCH}_{3}\right), 1.44-1.26\left(m, 1 \mathrm{H}, \mathrm{CH}_{2} \mathrm{CH}_{3}\right)$, 1.14-0.96 $\left(m, 4 \mathrm{H}\right.$, overlap $\mathrm{CH}_{2} \mathrm{CH}_{3}$ and $\left.\mathrm{CHCH}_{3}\right), 0.83(t, \mathrm{~J}$ $\left.=7.4 \mathrm{~Hz}, 3 \mathrm{H}, \mathrm{CH}_{2} \mathrm{CH}_{3}\right) .{ }^{13} \mathrm{C}-\mathrm{NMR}\left(67.5 \mathrm{MHz}, \mathrm{CDCl}_{3}\right)$ : 195.6, 164.5, $157.0\left(q,{ }^{2} J(\mathrm{C}, \mathrm{F})=37.4 \mathrm{~Hz}\right), 131.1(2 \mathrm{x} \mathrm{CH})$, 127.5, $115.9\left(q,{ }^{1} J(\mathrm{C}, \mathrm{F})=287.9 \mathrm{~Hz}\right), 114.2(2 \times \mathrm{CH}), 58.0$, 55.5, 39.0, 23.7, 16.2, 11.3. HR-MS: $340.1132\left([M+\mathrm{Na}]^{+}\right.$, $\mathrm{C}_{15} \mathrm{H}_{18} \mathrm{~F}_{3} \mathrm{NO}_{3} \mathrm{Na}^{+}$; calc. 340.1136).

3.5.4. 2,2,2-Trifluoro- $N-((2 S, 3 S)-3-m e t h y l-1-0 x 0-1-(p-$ tolyl)-pentan-2-yl)acetamide (TFA-L-Ile-Ph(4-Me), L-11).

Yield 65\%. Colorless needles. $[\alpha]_{\mathrm{D}}{ }^{23}=+83$ (c 1.0, $\mathrm{CHCl}_{3}$ ). IR (neat): 3302, 3022, 2925, 1700. ${ }^{1} \mathrm{H}-\mathrm{NMR}(270 \mathrm{MHz}$, $\left.\mathrm{CDCl}_{3}\right): 7.87\left(d,{ }^{3} J(\mathrm{H}, \mathrm{H})=8.2 \mathrm{~Hz}, 2 \mathrm{H}, \mathrm{Ar}-\mathrm{H}\right), 7.32\left(d,{ }^{3} J(\mathrm{H}\right.$, $\mathrm{H})=7.9 \mathrm{~Hz}, 2 \mathrm{H}, \mathrm{Ar}-\mathrm{H}), 5.57\left(d d,{ }^{3} J(\mathrm{H}, \mathrm{H})=8.7,4.1 \mathrm{~Hz}, 1 \mathrm{H}\right.$, $\mathrm{CHNH}), 2.45\left(\mathrm{~s}, 3 \mathrm{H}, \mathrm{CH}_{3}\right), 2.09-1.94\left(\mathrm{~m}, 1 \mathrm{H}, \mathrm{CHCH}_{3}\right)$, 1.40-1.25 ( $\left.m, 1 \mathrm{H}, \mathrm{CH}_{2} \mathrm{CH}_{3}\right), 1.12-0.94$ ( $m, 4 \mathrm{H}$, overlap $\mathrm{CH}_{2} \mathrm{CH}_{3}$ and $\left.\mathrm{CHCH}_{3}\right), 0.82\left(t,{ }^{3} J(\mathrm{H}, \mathrm{H})=7.3 \mathrm{~Hz}, 3 \mathrm{H}\right.$, $\left.\mathrm{CH}_{2} \mathrm{CH}_{3}\right) .{ }^{13} \mathrm{C}-\mathrm{NMR}\left(67.5 \mathrm{MHz}, \mathrm{CDCl}_{3}\right): 197.0,157.1$ (q, $\left.{ }^{2} J(\mathrm{C}, \mathrm{F})=37.4 \mathrm{~Hz}\right), 145.6,132.2(2 \times \mathrm{CH}), 129.8$ (2 x CH), 128.8, $115.9\left(q,{ }^{1} J(\mathrm{C}, \mathrm{F})=288.8 \mathrm{~Hz}\right), 58.3,38.9,23.7,21.8$, 16.2, 11.4. HR-MS: $302.1360\left(\left[M+\mathrm{H}^{+}, \mathrm{C}_{15} \mathrm{H}_{19} \mathrm{~F}_{3} \mathrm{NO}_{2}{ }^{+}\right.\right.$; calc. 302.1368).

3.5.5. 2,2,2-Trifluoro- $N$-((2S,3S)-1-(2,5-dimethylphenyl)3-methyl-1-oxopentan-2-yl)acetamide (TFA-L-Ile-Ph(2,5diMe), L-13)

Yield 78\%. Colorless needles. $[\alpha]_{\mathrm{D}}{ }^{23}=+68\left(\right.$ c 1.0, $\left.\mathrm{CHCl}_{3}\right)$. IR (neat): 3302, 3024, 2934, 1714, 1686, 1567. ${ }^{1} \mathrm{H}-\mathrm{NMR}$ (270 MHz, $\left.\mathrm{CDCl}_{3}\right): 7.50(s, 1 \mathrm{H}, \mathrm{Ar}-\mathrm{H}), 7.27\left(d,{ }^{3} J(\mathrm{H}, \mathrm{H})=\right.$ $7.6 \mathrm{~Hz}, 1 \mathrm{H}, \mathrm{Ar}-\mathrm{H}), 7.19\left(d,{ }^{3} J(\mathrm{H}, \mathrm{H})=7.8 \mathrm{~Hz}, 1 \mathrm{H}, \mathrm{Ar}-\mathrm{H}\right)$, $5.50\left(d d,{ }^{3} \mathrm{~J}(\mathrm{H}, \mathrm{H})=8.4,4.0 \mathrm{~Hz}, 1 \mathrm{H}, \mathrm{CHNH}\right), 2.45(\mathrm{~s}, 3 \mathrm{H}$, $\left.\mathrm{CH}_{3}\right), 2.39$ (s, 3H, $\left.\mathrm{CH}_{3}\right), 2.03-1.84\left(m, 1 \mathrm{H}, \mathrm{CHCH}_{3}\right), 1.38-$ $1.15\left(m, 1 \mathrm{H}, \mathrm{CH}_{2} \mathrm{CH}_{3}\right), 1.11-0.88\left(m, 4 \mathrm{H}\right.$ overlap $\mathrm{CH}_{2} \mathrm{CH}_{3}$ and $\left.\mathrm{CHCH}_{3}\right), 0.82\left(t,{ }^{3} J(\mathrm{H}, \mathrm{H})=7.3 \mathrm{~Hz}, 3 \mathrm{H}, \mathrm{CH}_{2} \mathrm{CH}_{3}\right)$. ${ }^{13} \mathrm{C}-\mathrm{NMR}\left(67.5 \mathrm{MHz}, \mathrm{CDCl}_{3}\right): 201.1,157.5\left(q,{ }^{2} \mathrm{~J}(\mathrm{C}, \mathrm{F})=\right.$ 37.4 Hz), 136.3, 136.0, 135.3, 133.6, 132.6, 129.7, 116.1 (q, $\left.{ }^{1} J(\mathrm{C}, \mathrm{F})=287.9 \mathrm{~Hz}\right), 60.2,38.5,24.2,20.9,20.5,16.1,11.5$. HR-MS: $316.1528\left([M+\mathrm{H}]^{+}, \mathrm{C}_{16} \mathrm{H}_{21} \mathrm{~F}_{3} \mathrm{NO}_{2}{ }^{+}\right.$; calc. 316.1524.

3.5.6. 2,2,2-Trifluoro- $N$-((2S,3S)-1-mesityl-3-methyl-1oxopentan-2-yl)acetamide (TFA-L-Ile-Ph(2,4,6-triMe), L-14)

Yield 70\%. Colorless needles. [n- ${ }^{23}=+69$ (c 2.0, $\left.\mathrm{CHCl}_{3}\right)$. IR (neat): 3333, 2968, 1611, 1544. ${ }^{1} \mathrm{H}-\mathrm{NMR}(270 \mathrm{MHz}$, $\left.\mathrm{CDCl}_{3}\right): 7.14\left(d,{ }^{3} J(\mathrm{H}, \mathrm{H})=9.1 \mathrm{~Hz}, 1 \mathrm{H}, \mathrm{NH}\right), 6.90(\mathrm{~s}, 2 \mathrm{H}$, Ar-H), $5.23\left(d d,{ }^{3} J(\mathrm{H}, \mathrm{H})=9.1,2.8 \mathrm{~Hz}, 1 \mathrm{H}, \mathrm{CHNH}\right), 2.31$ (s, $\left.3 \mathrm{H}, \mathrm{CH}_{3}\right), 2.26\left(\mathrm{~s}, 6 \mathrm{H}, 2 \times \mathrm{CH}_{3}\right), 1.93-1.76(\mathrm{~m}, 1 \mathrm{H}$, $\left.\mathrm{CHCH}_{3}\right), 1.56-1.36\left(m, 1 \mathrm{H}, \mathrm{CH}_{2} \mathrm{CH}_{3}\right), 1.15-0.94(m, 4 \mathrm{H}$, overlap $\mathrm{CH}_{2} \mathrm{CH}_{3}$ and $\left.\mathrm{CHCH}_{3}\right), 0.89(t, J=7.2 \mathrm{~Hz}, 3 \mathrm{H}$, $\left.\mathrm{CH}_{2} \mathrm{CH}_{3}\right) .{ }^{13} \mathrm{C}-\mathrm{NMR}\left(67.5 \mathrm{MHz}, \mathrm{CDCl}_{3}\right): 205.8,157.3$ (q, $\left.{ }^{2} J(\mathrm{C}, \mathrm{F})=37.5 \mathrm{~Hz}\right), 140.5,135.9,134.9,129.7,116.0(\mathrm{q}$, $\left.{ }^{1} J(C, F)=286.4 \mathrm{~Hz}\right), 64.0,36.9,23.2,21.1,19.7,17.1,11.4$. HR-MS: $\quad 330.1674 \quad\left(\left[M+\mathrm{H}^{+}, \quad \mathrm{C}_{17} \mathrm{H}_{23} \mathrm{~F}_{3} \mathrm{NO}_{2}{ }^{+}\right.\right.$; calc. 330.1680).

3.5.7. 2,2,2-Trifluoro- $N-((2 S, 3 R)-3-m e t h y l-1-0 x 0-1-$ phenyl-pentan-2-yl)acetamide (TFA-L-allo-Ile-Ph, L-8). Yield 90\%. Colorless needles. $[\alpha]_{\mathrm{D}}{ }^{23}=+79$ (c 2.0, $\mathrm{CHCl}_{3}$ ). IR (neat): 3335, 3068, 2971, 1741, 1693. ${ }^{1} \mathrm{H}-\mathrm{NMR}$ (270 $\left.\mathrm{MHz}, \mathrm{CDCl}_{3}\right): 7.97\left(d,{ }^{3} J(\mathrm{H}, \mathrm{H})=7.7 \mathrm{~Hz}, 2 \mathrm{H}, \mathrm{Ar}-\mathrm{H}\right), 7.65(t$, $\left.{ }^{3} J(\mathrm{H}, \mathrm{H})=7.7 \mathrm{~Hz}, 1 \mathrm{H}, \mathrm{Ar}-\mathrm{H}\right), 7.53\left(t,{ }^{3} J(\mathrm{H}, \mathrm{H})=7.7 \mathrm{~Hz}, 2 \mathrm{H}\right.$, Ar-H), $7.29(b r s, 1 \mathrm{H}, \mathrm{NH}), 5.74\left(d d,{ }^{3} J(\mathrm{H}, \mathrm{H})=8.6,2.3 \mathrm{~Hz}\right.$, 1H, CHNH), 2.09-1.93 (m, 1H, $\left.\mathrm{CHCH}_{3}\right), 1.67-1.50(m, 1 \mathrm{H}$, $\left.\mathrm{CH}_{2} \mathrm{CH}_{3}\right), 1.38-1.22\left(m, 1 \mathrm{H}, \mathrm{CH}_{2} \mathrm{CH}_{3}\right), 1.06\left(t,{ }^{3} J(\mathrm{H}, \mathrm{H})=\right.$ $\left.7.3 \mathrm{~Hz}, 3 \mathrm{H}, \mathrm{CH}_{2} \mathrm{CH}_{3}\right), 0.77\left(d,{ }^{3} J(\mathrm{H}, \mathrm{H})=6.9 \mathrm{~Hz}, 3 \mathrm{H}\right.$, $\left.\mathrm{CHCH}_{3}\right) .{ }^{13} \mathrm{C}-\mathrm{NMR}\left(67.5 \mathrm{MHz}, \mathrm{CDCl}_{3}\right): 197.2,157.3$ (q, $\left.{ }^{2} J(C, F)=37.2 \mathrm{~Hz}\right), 134.4,134.1,129.1(2 \mathrm{x} \mathrm{CH}), 128.7$ (2 x $\mathrm{CH}), 115.9\left(q,{ }^{1} J(\mathrm{C}, \mathrm{F})=287.7 \mathrm{~Hz}\right), 57.1,38.7,27.3,13.4$, 12.0. HR-MS: $288.1236\left(\left[M+\mathrm{H}^{+}, \mathrm{C}_{14} \mathrm{H}_{17} \mathrm{~F}_{3} \mathrm{NO}_{2}{ }^{+}\right.\right.$; calc. 288.1211).

3.5.8. 2,2,2-Trifluoro- $N-((2 R, 3 S)-3-m e t h y l-1-o x o-1-$ phenylpentan-2-yl)acetamide (TFA-D-allo-Ile-Ph, D-8).

Yield 96\%. Colorless needles. $[\alpha]_{\mathrm{D}}{ }^{23}=-79$ (с 2.0, $\mathrm{CHCl}_{3}$ ). IR (neat): 3331, 3067, 2969, 1738, 1692. ${ }^{1} \mathrm{H}-\mathrm{NMR}(270$ $\left.\mathrm{MHz} \mathrm{CDCl}_{3}\right): 7.98\left(d,{ }^{3} J(\mathrm{H}, \mathrm{H})=7.3 \mathrm{~Hz}, 2 \mathrm{H}, \mathrm{Ar}-\mathrm{H}\right), 7.66(t$, $\left.{ }^{3} J(\mathrm{H}, \mathrm{H})=7.3 \mathrm{~Hz}, 1 \mathrm{H}, \mathrm{Ar}-\mathrm{H}\right), 7.54\left(t,{ }^{3} \mathrm{~J}(\mathrm{H}, \mathrm{H})=7.3 \mathrm{~Hz}, 2 \mathrm{H}\right.$, Ar-H), $5.74\left(d d,{ }^{3} J(\mathrm{H}, \mathrm{H})=8.6,2.3 \mathrm{~Hz}, 1 \mathrm{H}, \mathrm{CHNH}\right), 2.07-$ $1.96\left(m, 1 \mathrm{H}, \mathrm{CHCH}_{3}\right), 1.66-1.49\left(m, 1 \mathrm{H}, \mathrm{CH}_{2} \mathrm{CH}_{3}\right), 1.38$ $1.21\left(m, 1 \mathrm{H}, \mathrm{CH}_{2} \mathrm{CH}_{3}\right), 1.06\left(t,{ }^{3} J(\mathrm{H}, \mathrm{H})=7.3 \mathrm{~Hz}, 3 \mathrm{H}\right.$, $\left.\mathrm{CH}_{2} \mathrm{CH}_{3}\right), 0.76\left(d,{ }^{3} J(\mathrm{H}, \mathrm{H})=6.9 \mathrm{~Hz}, 3 \mathrm{H}, \mathrm{CHCH}_{3}\right) .{ }^{13} \mathrm{C}-$ NMR (67.5 MHz, $\left.\mathrm{CDCl}_{3}\right)$ : 197.1, $157.3\left(q,{ }^{2} J(\mathrm{C}, \mathrm{F})=37.4\right.$ $\mathrm{Hz}), 134.3$, 134.1, 129.1 ( 2 x CH), 128.7 (2 x CH), 115.9 (q, $\left.{ }^{1} \mathrm{~J}(\mathrm{C}, \mathrm{F})=287.9 \mathrm{~Hz}\right), 57.1,38.7,27.3,13.4,12.0$. HR-MS: $288.1234\left([M+\mathrm{H}]^{+}, \mathrm{C}_{14} \mathrm{H}_{17} \mathrm{~F}_{3} \mathrm{NO}_{2}{ }^{+}\right.$; calc. 288.1211).

3.5.9. 2,2,2-Trifluoro- $N$-(2-oxo-2-phenylethyl)acetamide (TFA-Gly-Ph, 17) [9].

Yield 90\%. Colorless oil. IR (neat): 3327, 3104, 2927, 1732, 1703. ${ }^{1} \mathrm{H}-\mathrm{NMR}\left(270 \mathrm{MHz} \mathrm{CDCl}_{3}\right): 7.96\left(d,{ }^{3} \mathrm{~J}(\mathrm{H}, \mathrm{H})=7.3\right.$ $\mathrm{Hz}, 2 \mathrm{H}, \mathrm{Ar}-\mathrm{H}), 7.65\left(t,{ }^{3} J(\mathrm{H}, \mathrm{H})=7.4 \mathrm{~Hz}, 1 \mathrm{H}, \mathrm{Ar}-\mathrm{H}\right), 7.52(t$, $\left.{ }^{3} J(\mathrm{H}, \mathrm{H})=7.4 \mathrm{~Hz}, 2 \mathrm{H}, \mathrm{Ar}-\mathrm{H}\right), 4.80\left(d,{ }^{3} J(\mathrm{H}, \mathrm{H})=4.3 \mathrm{~Hz}, 2 \mathrm{H}\right.$, $\left.\mathrm{CH}_{2} \mathrm{NH}\right) .{ }^{13} \mathrm{C}-\mathrm{NMR}\left(67.5 \mathrm{MHz}, \mathrm{CDCl}_{3}\right)$ : 192.0, 157.2 (q, $\left.{ }^{2} J(\mathrm{C}, \mathrm{F})=35.8 \mathrm{~Hz}\right), 134.7,133.6,129.1$ (2 x CH), 128.0 (2 x $\mathrm{CH}), 115.7$ ( $\left.q,{ }^{1} \mathrm{~J}(\mathrm{C}, \mathrm{F})=287.2 \mathrm{~Hz}\right), 46.2$. HR-MS: 232.0565 $\left([M+\mathrm{H}]^{+}, \mathrm{C}_{10} \mathrm{H}_{9} \mathrm{~F}_{3} \mathrm{NO}_{2}{ }^{+}\right.$; calc. 232.0585).

3.5.10. (S)-2,2,2-trifluoro- $N$-(1-oxo-1-phenylpropan-2-yl)acetamide (TFA-L-Ala-Ph, L-20) [7,10,31].

Yield 88\%. Colorless oil. $=-7\left(\mathrm{c} 1.0, \mathrm{CHCl}_{3}\right)$. IR (neat): 3331, 3070, 2991, 1738, 1701. ${ }^{1} \mathrm{H}-\mathrm{NMR}\left(270 \mathrm{MHz}, \mathrm{CDCl}_{3}\right)$ : $7.99\left(d,{ }^{3} J(\mathrm{H}, \mathrm{H})=7.6 \mathrm{~Hz}, 2 \mathrm{H}, \mathrm{Ar}-\mathrm{H}\right), 7.67\left(t,{ }^{3} J(\mathrm{H}, \mathrm{H})=7.4\right.$ $\mathrm{Hz}, 1 \mathrm{H}, \mathrm{Ar}-\mathrm{H}), 7.54\left(t,{ }^{3} \mathrm{~J}(\mathrm{H}, \mathrm{H})=7.4 \mathrm{~Hz}, 2 \mathrm{H}, \mathrm{Ar}-\mathrm{H}\right), 5.60-$ $5.50\left(m, 1 \mathrm{H}, \mathrm{CHCH}_{3}\right), 1.53\left(d,{ }^{3} J(\mathrm{H}, \mathrm{H})=7.3 \mathrm{~Hz}, 3 \mathrm{H}\right.$, $\left.\mathrm{CHCH}_{3}\right) .{ }^{13} \mathrm{C}-\mathrm{NMR}\left(67.5 \mathrm{MHz} \mathrm{CDCl}_{3}\right): 197.0,156.5$ (q, $\left.{ }^{2} J(\mathrm{C}, \mathrm{F})=37.4 \mathrm{~Hz}\right), 134.5,133.0,129.1(2 \times \mathrm{CH}), 128.8(2 \mathrm{x}$ $\mathrm{CH}), 115.7\left(q,{ }^{1} J(\mathrm{C}, \mathrm{F})=288.1 \mathrm{~Hz}\right), 50.8,19.2$. HR-MS: 246.0748 ([M+ H] $]^{+}, \mathrm{C}_{11} \mathrm{H}_{11} \mathrm{~F}_{3} \mathrm{NO}_{2}{ }^{+}$; calc. 246.0742).

3.5.11. (R)-2,2,2-Trifluoro- $N$-(1-oxo-1-phenylpropan-2yl)-acetamide (TFA-D-Ala-Ph, D-20).

Yield 94\%. Colorless oil. $[\alpha]_{\mathrm{D}}^{23}=+7$ (c 1.0, $\mathrm{CHCl}_{3}$ ). IR (neat): 3337, 3091, 2948, 1725, 1700. ${ }^{1} \mathrm{H}-\mathrm{NMR}(270 \mathrm{MHz}$, $\left.\mathrm{CDCl}_{3}\right): 7.99\left(d,{ }^{3} J(\mathrm{H}, \mathrm{H})=7.3 \mathrm{~Hz}, 2 \mathrm{H}, \mathrm{Ar}-\mathrm{H}\right), 7.67\left(t,{ }^{3} J(\mathrm{H}\right.$, $\mathrm{H})=7.4 \mathrm{~Hz}, 1 \mathrm{H}, \mathrm{Ar}-\mathrm{H}), 7.54\left(t,{ }^{3} J(\mathrm{H}, \mathrm{H})=7.6 \mathrm{~Hz}, 2 \mathrm{H}, \mathrm{Ar}-\right.$ $\mathrm{H}), 5.60-5.49\left(m, 1 \mathrm{H}, \mathrm{CHCH}_{3}\right), 1.53\left(d,{ }^{3} J(\mathrm{H}, \mathrm{H})=6.9 \mathrm{~Hz}\right.$, $\left.3 \mathrm{H}, \mathrm{CHCH}_{3}\right) .{ }^{13} \mathrm{C}-\mathrm{NMR}\left(67.5 \mathrm{MHz}, \mathrm{CDCl}_{3}\right): 197.0,156.5$ (q, $\left.{ }^{2} J(\mathrm{C}, \mathrm{F})=37.4 \mathrm{~Hz}\right), 134.5,132.9,129.1(2 \mathrm{x} \mathrm{CH}), 128.8(2 \mathrm{x}$ $\mathrm{CH}), 115.7\left(q,{ }^{1} J(\mathrm{C}, \mathrm{F})=287.7 \mathrm{~Hz}\right), 50.8,19.3$. HR-MS: $246.0747\left(\left[M+\mathrm{H}^{+}, \mathrm{C}_{11} \mathrm{H}_{11} \mathrm{~F}_{3} \mathrm{NO}_{2}{ }^{+}\right.\right.$; calc. 246.0742).

3.5.12. (S)- $N, N^{\prime}$-(6-Oxo-6-phenylhexane-1,5-diyl)bis(2,2,2-trifluoroacetamide) (TFA-L-Lys(TFA)-Ph, L-23).

Yield 88\%. Colorless amorphous mass. $[\alpha]_{\mathrm{D}}^{23}=+10$ (с 1.0, $\left.\mathrm{CHCl}_{3}\right)$. IR (neat): 3317, 3097, 2947, 1719. ${ }^{1} \mathrm{H}-\mathrm{NMR}(270$ $\left.\mathrm{MHz}_{\mathrm{CDCl}}\right): 7.97\left(d,{ }^{3} \mathrm{~J}(\mathrm{H}, \mathrm{H})=7.3 \mathrm{~Hz}, 2 \mathrm{H}, \mathrm{Ar}-\mathrm{H}\right), 7.68(t$, $\left.{ }^{3} J(\mathrm{H}, \mathrm{H})=7.4 \mathrm{~Hz}, 1 \mathrm{H}, \mathrm{Ar}-\mathrm{H}\right), 7.55\left(t,{ }^{3} J(\mathrm{H}, \mathrm{H})=7.6 \mathrm{~Hz}, 2 \mathrm{H}\right.$, Ar-H), $6.69(b r s$, , $1 \mathrm{H}, \mathrm{NH}), 5.60\left(t d,{ }^{3} J(\mathrm{H}, \mathrm{H})=7.7,3.8 \mathrm{~Hz}\right.$, 
$1 \mathrm{H}, \mathrm{CHNH}), 3.32\left(q,{ }^{3} \mathrm{~J}(\mathrm{H}, \mathrm{H})=6.5 \mathrm{~Hz}, 2 \mathrm{H}, \mathrm{CH}_{2} \mathrm{NH}\right), 2.10$ $2.03\left(m, 1 \mathrm{H}, \mathrm{CHCH}_{2} \mathrm{CH}_{2}\right), 1.80-1.50(m, 3 \mathrm{H}$, overlap $\mathrm{CHCH}_{2} \mathrm{CH}_{2}$ and $\left.\mathrm{CH}_{2} \mathrm{CH}_{2} \mathrm{NH}\right), \quad 1.48-1.26 \quad(m, 2 \mathrm{H}$, $\left.\mathrm{CHCH}_{2} \mathrm{CH}_{2}\right) .{ }^{13} \mathrm{C}-\mathrm{NMR}\left(67.5 \mathrm{MHz}, \mathrm{CDCl}_{3}\right): 96.5,157.4(q$, $\left.{ }^{2} J(\mathrm{C}, \mathrm{F})=36.9 \mathrm{~Hz}\right), 157.2\left(q,{ }^{2} J(\mathrm{C}, \mathrm{F})=37.6 \mathrm{~Hz}\right), 134.7$, 133.3, 129.2, 128.6, $115.8\left(q,{ }^{1} J(\mathrm{C}, \mathrm{F})=287.7 \mathrm{~Hz}\right), 115.7(q$, $\left.{ }^{1} J(\mathrm{C}, \mathrm{F})=287.5 \mathrm{~Hz}\right), 54.0,39.3$, 32.6, 28.0, 21.8. HR-MS: $399.1136\left([M+\mathrm{H}]^{+}, \mathrm{C}_{16} \mathrm{H}_{17} \mathrm{~F}_{6} \mathrm{~N}_{2} \mathrm{O}_{3}{ }^{+}\right.$; calc. 399.1143).

\subsubsection{3. $\quad(R)-N, N^{\prime}-(6-O x o-6-p h e n y l h e x a n e-1,5-d i y l) b i s-$} (2,2,2-trifluoroacetamide) (TFA-D-Lys(TFA)-Ph, D-23).

Yield 93\%. Colorless amorphous mass. $[\alpha]_{\mathrm{D}}{ }^{23}=-10$ (c 1.0, $\mathrm{CHCl}_{3}$ ). IR (neat): 3319, 3093, 2947, 1733. ${ }^{1} \mathrm{H}-\mathrm{NMR}$ (270 $\left.\mathrm{MHz}, \mathrm{CDCl}_{3}\right): 7.97\left(d,{ }^{3} J(\mathrm{H}, \mathrm{H})=7.3 \mathrm{~Hz}, 2 \mathrm{H}, \mathrm{Ar}-\mathrm{H}\right), 7.68(t$, $\left.{ }^{3} J(\mathrm{H}, \mathrm{H})=7.4 \mathrm{~Hz}, 1 \mathrm{H}, \mathrm{Ar}-\mathrm{H}\right), 7.55\left(t,{ }^{3} \mathrm{~J}(\mathrm{H}, \mathrm{H})=7.6 \mathrm{~Hz}, 3 \mathrm{H}\right.$, Ar-H), $6.48(b r s, 1 \mathrm{H}, \mathrm{NH}), 5.60\left(t d,{ }^{3} \mathrm{~J}(\mathrm{H}, \mathrm{H})=7.7,3.8 \mathrm{~Hz}\right.$, $1 \mathrm{H}, \mathrm{CHNH}), 3.32\left(q,{ }^{3} \mathrm{~J}(\mathrm{H}, \mathrm{H})=6.8 \mathrm{~Hz}, 2 \mathrm{H}, \mathrm{CH}_{2} \mathrm{NH}\right), 2.14$ $2.00\left(m, 1 \mathrm{H}, \mathrm{CHCH}_{2} \mathrm{CH}_{2}\right), 1.81-1.51(m, 3 \mathrm{H}$, overlap $\mathrm{CHCH}_{2} \mathrm{CH}_{2}$ and $\left.\mathrm{CH}_{2} \mathrm{CH}_{2} \mathrm{NH}\right), \quad 1.50-1.24(m, 2 \mathrm{H}$, $\left.\mathrm{CHCH}_{2} \mathrm{CH}_{2}\right) .{ }^{13} \mathrm{C}-\mathrm{NMR}\left(67.5 \mathrm{MHz}, \mathrm{CDCl}_{3}\right): 196.5,157.5$ $\left(q,{ }^{2} J(\mathrm{C}, \mathrm{F})=37.1 \mathrm{~Hz}\right), 157.3\left(q,{ }^{2} J(\mathrm{C}, \mathrm{F})=37.8 \mathrm{~Hz}\right), 134.8$, 133.3, 129.3, 128.7, $115.8\left(q,{ }^{1} J(\mathrm{C}, \mathrm{F})=287.7 \mathrm{~Hz}\right), 115.8(q$, $\left.{ }^{1} J(\mathrm{C}, \mathrm{F})=287.5 \mathrm{~Hz}\right), 54.0,39.4,32.7,28.1$, 21.9. HR-MS: $399.1135\left([M+\mathrm{H}]^{+}, \mathrm{C}_{16} \mathrm{H}_{17} \mathrm{~F}_{6} \mathrm{~N}_{2} \mathrm{O}_{3}{ }^{+}\right.$; calc. 399.1143).

\section{CONCLUSION}

In conclusion, a TFA- $\alpha$-amino acid chloride formed by utilizing a Vilsmeier reagent and its application in the Friedel-Crafts acylation of arenes were developed as a convenient method for the synthesis of optically active TFA$\alpha$-amino aryl ketone. The use of isoleucine and its diastereomer allo-isoleucine was explored and proven to be an efficient way to monitor acid chloride formation and its application, since their epimeric $\alpha$-proton can be detected by ${ }^{1} \mathrm{H}-\mathrm{NMR}$ and used to check the retention of $\alpha$-proton chirality. Various TFA- $\alpha$-amino acid chlorides, formed by using a Vilsmeier reagent, can be used in the Friedel-Crafts acylation of arenes. This study contributes to the elaboration of alternative synthetic methods forimportant intermediates which have a wide range of applications in organic and biomolecular chemistry.

\section{CONSENT FOR PUBLICATION}

Not applicable.

\section{CONFLICT OF INTEREST}

The Authors confirm that this article contents has no conflict of interest.

\section{ACKNOWLEDGEMENTS}

Zetryana Puteri Tachrim thanks LPDP (Indonesia Endowment Fund for Education) for financial support. This research was partially supported by the Ministry of Education, Science, Sports, and Culture Grant-in-Aid for Scientific Research (C), (17K0194007 to Makoto Hashimoto). Part of this work was performed under the Cooperative Research Program of "Network Joint Research Center for Materials and Devices".

\section{SUPPLEMENTARY MATERIAL}

NMR spectrums of all compounds are available on the WWW under http://dx.doi.org/xxx/xxx.

\section{REFERENCES}

[1] Joullie, M.M.; Lassen, K.M. Arkivoc, 2010, (8), 189-250.

[2] Jarrahpour, A.; Zarei, M. Tetrahedron, 2009, 65, 2927-2934.

[3] Varie, D.L. Tetrahedron Lett., 1990, 31(52), 7583-7586.

[4] Buckley, T.F.; Rapoport, H. J. Am. Chem. Soc., 1981, 103(20), 6157-6163.

[5] Di Gioia, M.L.; Leggio, A.; Liguori, A.; Napoli, A.; Siciliano, C.; Sindona, G. J. Org. Chem,. 2001, 66(21), 7002-7007.

[6] McClure, D.E.; Arison, B.H.; Jones, J.H.; Baldwin, J.J. J. Org. Chem., 1981, 46(11), 2431-2433.

[7] Nordlander, J.E.; Njoroge, F.G.; Payne, M.J.; Warman, D. J. Org. Chem., 1985, 50(19), 3481-3484.

[8] Pines, S.H.; Chemerda, J.M.; Kozlowski, M.A.; Weinstock, L.M.; Davis, P.; Handelsman, B.; Grenda, V.J.; Lindberg, G.W. J. Med. Chem., 1967, 10(4), 725-728.

[9] Nordlander, J.E.; Payne, M.J.; Njoroge, F.G.; Balk, M.A.; Laikos, G.D.; Vishwanath, V.M. J. Org. Chem., 1984, 49(22), 4107-4111.

[10] Katritzky, A.R.; Jiang, R.; Suzuki, K. J. Org. Chem., 2005, 70(13), 4993-5000.

[11] Tachrim, Z.P.; Oida, K.; Ikemoto, H.; Ohashi, F.; Kurokawa, N.; Hayashi, K.; Shikanai, M.; Sakihama, Y.; Hashidoko, Y.; Hashimoto, M. Molecules, 2017, 22(10),1748-1762.

[12] Tachrim, Z.P.; Oida, K.; Ohashi, F.; Wakasa, H.; Ikemoto, H.; Kurokawa, N.; Sakihama, Y.; Hashidoko, Y.; Suzuki, T.; Hashimoto, M. Heterocycles, 2018, 97(2), 877-893.

[13] Kurokawa, N.; Tokoro, Y.; Tachrim, Z.P.; Wakasa, H.; Sakihama, Y.; Hashidoko, Y.; Suzuki, T.; Hashimoto, M. Arkivoc, 2019, (5), 42-49.

[14] Prabhu, G.; Basavaprabhu; Narendra, N.; Vishwanatha, T.M.; Sureshbabu, V. V. Tetrahedron, 2015, 71(19), 2785-2832.

[15] Jass, P.A.; Rosso, V.W.; Racha, S.; Soundararajan, N.; Venit, J.J.; Rusowicz, A.; Swaminathan, S.; Livshitz, J.; Delaney, E.J. Tetrahedron, 2003, 59(45), 9019-9029.

[16] Schallenberg, E.E.; Calvin, M. J. Am. Chem. Soc., 1955, 77(10), 2779-2783.

[17] Souter, R.W. Gas chromatographic amines and related i. structural. J. Chromatogr., 1975, 108(2), 265-274.

[18] Su, W.; Weng, Y.; Jiang, L.; Yang, Y.; Zhao, L.; Chen, Z.; Li, Z.; Li, J. Org. Prep. Proced. Int., 2010, 42(6), 503-555.

[19] Fleš, D.; Balenović, B. J. Am. Chem. Soc., 1956, 78(13), 30723074.

[20] Fleš, D.; Majhofer, B.; Kovač, M. Tetrahedron, 1968, 24(7), 30533057.

[21] Beckett, A.H.; Kirk, G.; Sharpen, A.J. Tetrahedron, 1965, 21(6), 1489-1493.

[22] Proctor, G.R.; Thomson, R.H. J. Chem. Soc., 1957, 2302-2311.

[23] Steglich, W.; Hinze, S. Synthesis, 1976, 399-401.

[24] Curphey, T.J. J. Org. Chem., 1979, 44(15), 2805-2807.

[25] Deblander, J.; Van Aeken, S.; Jacobs, J.; De Kimpe, N.; Tehrani, K.A. Eur. J. Org. Chem., 2009, 4882-4892.

[26] Weygand, F.; Ropsch, Chem. Ber., 1959, 92(9), 2095-2099.

[27] Fones, W.S.; Lee, M. J. Biol. Chem. 1954, 210(1), 227-238.

[28] Reay, A.J.; Williams, T.J.; Fairlamb, I.J.S. Org. Biomol. Chem., 2015, 13(30), 8298-8309.

[29] Kricheldorf, H.R.; Fehrle, M. Synthesis, 1974, 420-422.

[30] Cherevin, M.S.; Gulevich, T.G.; Popova, L.A.; Zubreichuk, Z.P.; Knizhnikov, V.A. Russ. J. Org. Chem., 2007, 43(10), 1427-1431.

[31] Davis, F.A.; Chai, J. Arkivoc, 2008, (2), 190-203. 